\title{
Cell Adhesion Molecules Regulating Neurite Growth from Amacrine and Rod Photoreceptor Cells
}

\author{
Ivar J. Kljavin, ${ }^{1,2}$ Carl Lagenaur, ${ }^{3}$ John L. Bixby, ${ }^{4}$ and Thomas A. Reh ${ }^{2}$ \\ 'University of Calgary, Department of Neuroscience, Calgary, Alberta, Canada T2N 4N1, 2University of Washington, \\ Department of Biological Structure, Seattle, Washington 98401 3 University of Pittsburgh, Department of Neurobiology, \\ Anatomy and Cell Science, Pittsburgh, Pennsylvania 15261, and ${ }^{4}$ University of Miami School of Medicine, Department of \\ Pharmacology, Miami, Florida 33136
}

\begin{abstract}
A great deal is now known about the cell adhesion molecules (CAMs) that are responsible for promoting the growth of ganglion cell axons as they project out of the retina through the optic nerve and finally to distant targets in the brain. However, the CAMs important for regulating axon outgrowth from nonprojection neurons, such as amacrine cells and rods, are not known. Such local circuit neurons extend their neurites rather short distances on cellular surfaces not normally encountered by the ganglion cell axons. To study the mechanisms regulating axon or dendrite growth from local circuit neurons, neurite outgrowth from amacrine cells and rod photoreceptor cells derived from the rat was examined in vitro on immunopurified forms of NCAM, L1, and N-cadherin, three well-characterized adhesive molecules found in the developing retina. Either early $(P 3)$ or late $(P 10)$ postnatal amacrine cells grew neurites on all three CAMs, but there were significant differences in the percentage of the amacrine cells that responded to each CAM. None of the CAMs supported neurite outgrowth from early postnatal rods, but, surprisingly, NCAM stimulated vigorous neurite extension from rods isolated at postnatal day 10 . Postnatal ganglion cells were also examined for comparison and were found not to grow neurites on NCAM, but did grow extensive processes on $\mathrm{L} 1$ and $\mathrm{N}$-cadherin. These results show that NCAM, L1, and $\mathbf{N}$-cadherin can promote neurite outgrowth from local circuit neurons, but that the effectiveness of any particular CAM is dependent on the cell type and the developmental period.
\end{abstract}

IKey words: cell adhesion molecules, NCAM, L1, N-cadherin, retina, amacrine cell, rod photoreceptor cell, retinal ganglion cell, neurite growth]

\footnotetext{
Received Oct. 14, 1993; revised Feb. 7, 1994; accepted Feb. 24, 1994.

We thank Drs. Kent Morest, Denis Dacey, Gerald Grunwald, Vance Lemmon, and Ray Anchan for discussions on this work. Thanks also to Dr. William Stell for reading carlier versions of the manuscript and to Kirsten Whiting for technical help. This study was supported by a Grant in Aid from Sigma-Xi to I.J.K., NIH ROI NS28308 and NS30305 to T.A.R. NIH EY05308 to C.L., and NSF IBN9309526 and NIH HD 25154 to J.L.B. I.J.K. was supported by the Alberta Heritage Foundation for Medical Research, Canada, Medical Research Council of Canada, and NIH RO1 NS28308.

Correspondence should be addressed to Ivar J. Kljavin, University of California, Department of Molecular and Cell Biology, 142 Life Sciences Addition, Berkeley, CA 94720.

Copyright (C) 1994 Society for Neuroscience $0270-6474 / 94 / 145035 \cdot 15 \$ 05.00 / 0$
}

During development of the CNS, some neurons grow their axons considerable distances into long fiber tracts to find their appropriate synaptic targets. Other neurons, however, project their axons or dendrites only short distances to terminate onto neighboring cells, forming local circuits. These "nonprojection" or local-circuit neurons not only make up the majority of neural elements throughout the nervous system, but are directly responsible for many complex facets of information processing (e.g., Werblin and Dowling, 1969; Kaneko, 1970; DeVries and Baylor, 1993). Within the retina, the complex synaptic organization of local-circuit neurons has been studied extensively over the past century, (Polyak, 1941; Ramon y Cajal, 1973), and in recent years an enormous amount of information about the different retinal cell types and the distribution and extent of their neuritic processes has been derived from intracellular staining and immunological studies (e.g., Vaney, 1984; Dacey, 1988; Rodiek, 1988; Giovanni and Brecha 1993). However, as is the case for other areas of the CNS, very little is known about the factors that regulate the growth of processes from local circuit neurons. A knowledge of these factors is prerequisite for understanding how the complex local circuitry is established during development.

Much of our knowledge about the factors that are responsible for promoting and guiding the growth of retinal neurons has come from studies of the retinal ganglion cell (RGC). During development, these projection neurons extend their axons out of the retina through the optic nerve and finally to distant targets in the brain. Cellular substrates contacted by ganglion cell growth cones include the surfaces of neuroepithelial and Müller cell end feet (Silver and Rutishauser, 1984) and astrocytes within the optic tract. In addition, RGC axons have a strong tendency to fasciculate with other axons in the developing optic nerve (Silver and Sidman, 1980; Krayanek and Goldberg, 1981). Localized to these surfaces are a variety of molecules, both bound to the cell membrane and deposited extracellularly, that have been shown to regulate neurite extension from ganglion cells in either a positive or negative manner (Silver and Rutishauser, 1984; Cohen et al., 1987; McLoon et al., 1988; Drazha and I emmon, 1990; Doherty et al., 1991; Snow et al., 1991; Baier and Bonhoeffer, 1992). However, since the majority of neurons in the vertebrate retina exhibit an extensive network of relatively short processes, they never come in contact with the same microenvironment as that of RGC axons. As a consequence, little is known about the factors that regulate neurite growth from these other retinal cell types. 
Some of the possible factors important for regulating the growth of retinal local circuit neurons are cell adhesion molecules (CAMs). At least three CAMs, NCAM, L1, and N-cadherin are localized along the optic pathway, and have been shown to be important mediators of retinal ganglion cell neurite outgrowth in vitro (Matsunaga et al., 1988; Doherty et al., 1990; Drazba and Lemmon, 1990). In addition, these molecules are localized to regions of potential significance for mediating neurite growth from other retinal neurons (Thiery et al., 1978; Daniloff et al., 1986; Hatta and Takeichi, 1986; Lemmon and McLoon, 1986; Matsunaga et al., 1988b). For example, depending on the developmental time, NCAM and $\mathrm{N}$-cadherin are diffusely distributed among all the retinal cell types, while $\mathrm{L} 1$ is found within both inner and outer plexiform layers. Therefore, the following experiments were undertaken to determine in vitro whether NCAM, L1, or N-cadherin function as neurite growth promoting molecules for two classes of retinal nonprojection neuronsamacrine cells and rod photoreceptors derived from the rat retina. For these studies, we cultured dissociated rat retinal cells at low density onto nitrocellulose coated coverslips that were "blotted" with purified preparations of these CAMs. Our data show that all three molecules can stimulate the outgrowth of neurites from these nonprojection neurons, but that the relative effectiveness of any particular CAM is dependent on the cell type and developmental period.

\section{Materials and Methods}

Animals and cell culture. Long Evans rat pups were killed by decapitation following $\mathrm{CO}_{2}$ anesthesia and the eyes were removed under sterile conditions. The neural retina was dissected away from the pigment epithelium and other ocular tissue in sterile basal salt solution (BSS) and dissociated into a single cell suspension using $0.25 \%$ trypsin in $\mathrm{Ca}^{2+} / \mathrm{Mg}^{2+}-$ free BSS. The retinas were incubated at $37^{\circ} \mathrm{C}$ in this solution for 7-10 min for P3 retina and up to $15 \mathrm{~min}$ for P10 retina, after which the trypsin was inactivated by adding $0.5 \mathrm{ml}$ of fetal bovine serum. The cells were plated at a density of 10-50,000 cells/well (24-well plates, 1 $\mathrm{ml}$ /well) in DMEM:F1 2 (without glutamate or aspartate, GIBCO) supplemented with insulin, $(25 \mu \mathrm{g} / \mathrm{ml})$, transferrin, $(100 \mu \mathrm{g} / \mathrm{ml})$, putrescine, $(60 \mathrm{\theta M})$, selenium $(30 \mathrm{nM})$, progesterone $(20 \mathrm{nM})$, and $1 \%$ fetal calf serum. Cells for all experiments were grown at $37^{\circ} \mathrm{C}$ in an atmosphere of $5 \%$ $\mathrm{CO}$.

Preparation of culture substrates. Glass coverslips (12 $\mathrm{mm}$ circles) were first coated with poly-D-lysine $(100 \mu \mathrm{g} / \mathrm{ml}$; Sigma) and then with nitrocellulose as described previously (Lagenaur and Lemmon, 1987). Briefly, a $4 \mathrm{~cm}^{2}$ strip of nitrocellulose was dissolved in $15 \mathrm{ml}$ of HPLC grade methanol. The surfaces of the coverslips were coated with approximately $100 \mu \mathrm{l}$ of this solution and allowed to dry under a laminar flow hood. This step was repeated two more times to ensure that an even coating of nitrocellulose prevented cells from coming in contact with the polylysine surface. On different coverslips, $4 \mu$ l aliquots of affinity-purified NCAM, Ll, and $\mathrm{N}$-cadherin were placed onto the center of the coverslips. NCAM and L1. proteins were derived from detergent extracts of early postnatal mouse brain as previously described (Lagenaur and Lemmon, 1987). The $\mathrm{N}$-cadherin protein was derived from detergent extracts of chicken brain as previously characterized elsewhere (Bixby and Zhang, 1990). The concentrations blotted on to the coverslips was approximately $80 \mu \mathrm{g} / \mathrm{ml}$ for NCAM and $\mathrm{Ll}$ and $25 \mu \mathrm{g} / \mathrm{ml}$ for N-cadherin unless otherwise indicated. After $30 \mathrm{~min}$ at $4^{\circ} \mathrm{C}$, the proteins were removed without drying and the coverslips washed twice with final medium containing no serum. For some experiments, coverslips were incubated for $30 \mathrm{~min}$ at $37^{\circ} \mathrm{C}$ with final medium containing $10 \%$ horse serum. In these cases, the number of cells adhering to the nitrocellulose outside the boundarics of the protcin dot was limited. In those experiments in which substrates were not incubated with media containing horse serum prior to plating cells, many cells were present on the uncoated regions, but these never responded by growing neurites (data not shown)

Antibody perturbation experiments. To demonstrate that neurite growth on the substrates can be blocked by specific antibodies to their corresponding cell adhesion molecules the following reagents were used. Poly- clonal antibodies with functional blocking activity for NCAM and L1 (Dr. C. Lagenaur; Chung et al., I991) were purified for total IgG first by ammonium sulfate precipitation and then by affinity chromatography using protein A-Sepharose. Fab' fragments of NCAM and L1 polyclonal antibodies were prepared by pepsin digestion (Porter, 1959) and residual intact IgG removed by chromatography on protein A-sepharose. Purity and completeness of digestion was verified by SDS-PAGF. Ta block the function of $\mathrm{N}$-cadherin, the monoclonal antibody NCD2 from ascites was used (Matsunaga et al., 1988; Bixby and Zhang, 1990). NCD2 ascites was produced by injecting NCD2 hybridoma cells (gift of Dr. M. Takeichi, Japan), intraperitoneally (i.p.) into male nude $\mathrm{Nu} / \mathrm{Nu}$ mice (8 weeks old) following the protocol outlined in Harlow and Lane, 1988. For the blocking experiments, Fab's to the NCAM and Ll antibodies $(1 \mathrm{mg} / \mathrm{ml})$ and NCD2 antibody from ascites (diluted 1:10) was added to the corresponding and noncorresponding CAM coated coverslips for $2-3 \mathrm{hr}$ at $37^{\circ} \mathrm{C}$ prior to plating the cells.

Immunohistochemical identification of cells in culture. For immunohistochemistry of cultured cells, retinal cultures were fixed using $4 \%$ paraformaldehyde containing $4 \%$ sucrose for $6-12 \mathrm{hr}$ at $4^{\circ} \mathrm{C}$. For rod photoreceptor cells, the monoclonal antibody against rhodopsin, Rho4D2 was used and was obtained from a hybridoma cell line (the generous gift of Drs. R. Molday and D. Hicks, University of British Columbia; Hicks and Barnstable, 1987). Supernatant from hybridoma culture medium was used without dilution, while ascites fluid from these cells was typically diluted 1:100. For amacrine cells, a monoclonal antibody directed against cellular retinoic acid binding protein (CRABP; obtained from Dr. Saari, University of Washington) was used. Details of the specificity and staining characteristics of anti-CRABP in culture are described in the Results, and the characterization of CRABP labeling in retinal sections has been detailed elsewhere (Bunt-Milam et al., 1989; De Leeuw et al., 1990; Gaur et al., 1990; Milam et al., 1990; BuntMilam and Sarri, 1993). Ascites fluid of CRABP was used at a concentration of $1: 200$ with $0.3 \%$ Triton X-100 in phosphate buffer overnight. For the identification of ganglion cells, postnatal day 2-3 rat pups were anesthetized on ice for 10-20 min and the optic tract injected with 1 $\mu \mathrm{l}$ of rhodamine dextran (Molecular Probes, Eugene, OR). After $24 \mathrm{hr}$ survival, the rats were killed and eyes prepared for culture as described above. In order to observe ganglion cell neurites, dextran-positive cells were labeled with the mouse monoclonal antibody Thy-1.1 (clone oX7, CedarLane, Canada). Indirect immunofluorescent labeling was carried out using fluorescein-conjugated secondary antibodies (anti-mouse IgG from Sigma Chemicals; $10 \mu \mathrm{g} / \mathrm{ml}$ ). Omission of the primary antibodies eliminated the observed immunoreactivity.

Analysis of retinal ganglion cell, amacrine cell, and rod photoreceptor cell neurite lengths. Ganglion, amacrine, and rod photoreceptor cells were examined after $18-24 \mathrm{hr}$ in culture or as indicated in the figure caption. The number of cells, and the number of experiments examined for each of the data points are indicated in the figure captions. The experiments presented in the results report the percentage of cells with neurites greater than two cell body diameters, neurite lengths (reported as length of longest primary neurite and total neurite output which is the length of all neurites grown by the identified cell), and percentage of cells with one, two, three, and four or more primary neurites greater than two cell body diameters. For measurements of neurite length, the cells with processes were examined at a final image magnification of $400 \times$. The fluorescence images of the cells were recorded with an image intensifier coupled to a CCD video camera (Motion Analysis, Eugene, OR) and analyzed with a Macintosh II image processing program (IMAGE 1.0, a public domain program, Wayne Rasband, NIH). Neurite lengths were measured by tracing the total length of the longest primary neurite, and the total length of all neurites extending from the cell bodies of retinal ganglion cells, amacrine cells, or rod photoreceptor cells. Recorded lengths were calibrated at the same magnification using a microscope slide micrometer.

Immunohistochemical labeling in tissue sections. Retinal sections were cut from postnatal eyes prepared as follows: postnatal rats were killed as described above and perfused (cardiac perfusion) with $4 \%$ paraformaldehyde in phosphate buffer. Retinas were removed and immersionfixed for an additional $12 \mathrm{hr}\left(4^{\circ} \mathrm{C}\right)$ and prepared for cryostat sectioning at $-20^{\circ} \mathrm{C}$. Sections were mounted onto gelatin coated glass slides and prepared for immunohistochemistry by first incubating the sections in a solution of $1 \% \mathrm{BSA}$. Antibodies used for the immunohistochemistry on tissue sections were as follows: NCAM and L1 rabbit polyclonal sera (Chun et al., 1991), and a rabbit polyclonal serum directed against an $\mathrm{N}$-cadherin fusion protein (gift from P. Doherty, Department of Pathology, Guy's Hospital, London; Doherty et al., 1991). For the NCAM 
Table 1. Percentage of cells immunoreactive for CRABP and Rho$4 \mathrm{D} 2$ after being plated onto various substrates at low density

\% Immunoreactive cells

\begin{tabular}{lcc} 
Substrate & \multicolumn{1}{c}{ CRABP } & Rho-4D2 \\
\hline NCAM & $7.9(2.1)$ & $14.5(4.1)$ \\
L1 & $7.5(2.4)$ & $12.6(2.1)$ \\
N-CAD & $10.0(0.6)$ & $11.6(3.2)$ \\
NC & $9.9(3.2)$ & $10.5(2.0)$ \\
\hline
\end{tabular}

Pairwise comparisons using the Student's $t$ test showed that there were no significant differences $(p>0.05)$ in the percentage of cells immunoreactive for CRABP, when plated onto NCAM, L1, N-cadherin, or nitrocellulose alone (NC). Similarly, there were no significant differences $(p>0.05)$ in the percentage of cells immunoreactive for rhodopsin, when plated onto any of the above substrates. These determinations were made by plating postnatal day 3 retinal cells $(10-50,000$ cells/ well, $24 \times 12 \mathrm{~mm}$ well culture plates) onto nitrocellulose-coated coverslips that were blotted with either NCAM $(80 \mu \mathrm{g} / \mathrm{ml}), \mathrm{L} 1(80 \mu \mathrm{g} / \mathrm{ml})$, or N-cadherin $(20 \mu \mathrm{g} /$ $\mathrm{ml}$; N-CAD). NC refers to nitrocellulose alone. Numbers in parentheses indicate SEM. None of the coverslips were coated with serum-containing media after blotting the proteins, and the cells were spun down onto the coverslips and maintained in culture for $24 \mathrm{hr}$. After culturing, the cells were carefully fixed by slowly adding fixative to the media so that the data would not reflect differences in number of cells adhering. These data show that CRABP and Rho-4D2 immunoreactivity does not change as a result of contact with different substrates, and that any differences in the number of cells with processes on the different substrates do not reflect such changes.

and $\mathrm{Ll}$ serum, total IgG was purified hrst by ammonium sulfate precipitation and then by affinity chromatography using protein A-sepharose as described above for the blocking experiments. Final antibody was diluted 1:1000 for use. For N-cadherin, the antibody was used as crude serum and diluted 1:500 for use. Antibody to CRABP was used as described above for the cultured cells, and all antibodies were visualized by indirect immunofluorescence as described above.

\section{Results}

Specific identification of amacrine cells, retinal ganglion cells, and rods in culture

The experiments were based on a cell culture assay in which amacrine cells, postnatal retinal ganglion cells, and rod photoreceptor cells derived from rat retina were specifically identified, and neurite outgrowth assessed on various molecular substrates. Amacrine cells were identified by immunofluorescence using a monoclonal antibody against bovine retina CRABP. This antibody reacts with a subpopulation of GABAergic rat amacrine cells as early as embryonic day 18 through adult ages (BuntMilam et al., 1989; De Leeuw et al., 1990; Gaur et al., 1990; Milam et al., 1990). As shown in Figure 1, $A$ and $B$, CRABP is localized exclusively to amacrine cells, staining cell bodies on both sides of the inner plexiform layer, as well as processes within this layer. In cultures of rat retinal cells derived from embryonic or postnatal animals, the antibody labeled cell bodies and the full extent of any neurites including their growth cones (Fig. 1C). Labeling was also seen in cells that were either freshly dissociated or maintained for several weeks in culture (data not shown). The labeling intensity, and the percentage of cells expressing CRABP was the same in postnatal retinal cultures in which cells were plated on a variety of substrates (Table 1), suggesting that CRABP immunoreactivity on amacrine cells is not regulated by contact with the different substrates studied here.

Importantly, amacrine cells in culture were clearly distinguished from ganglion cells in the following way: ganglion cells were labeled retrogradely with a fluorescent dextran by injecting the superior colliculus $(1 \mu \mathrm{l})$ with dextran-rhodamine $(10,000$ MW, Molecular Probes, Eugene, OR), which resulted in labeling
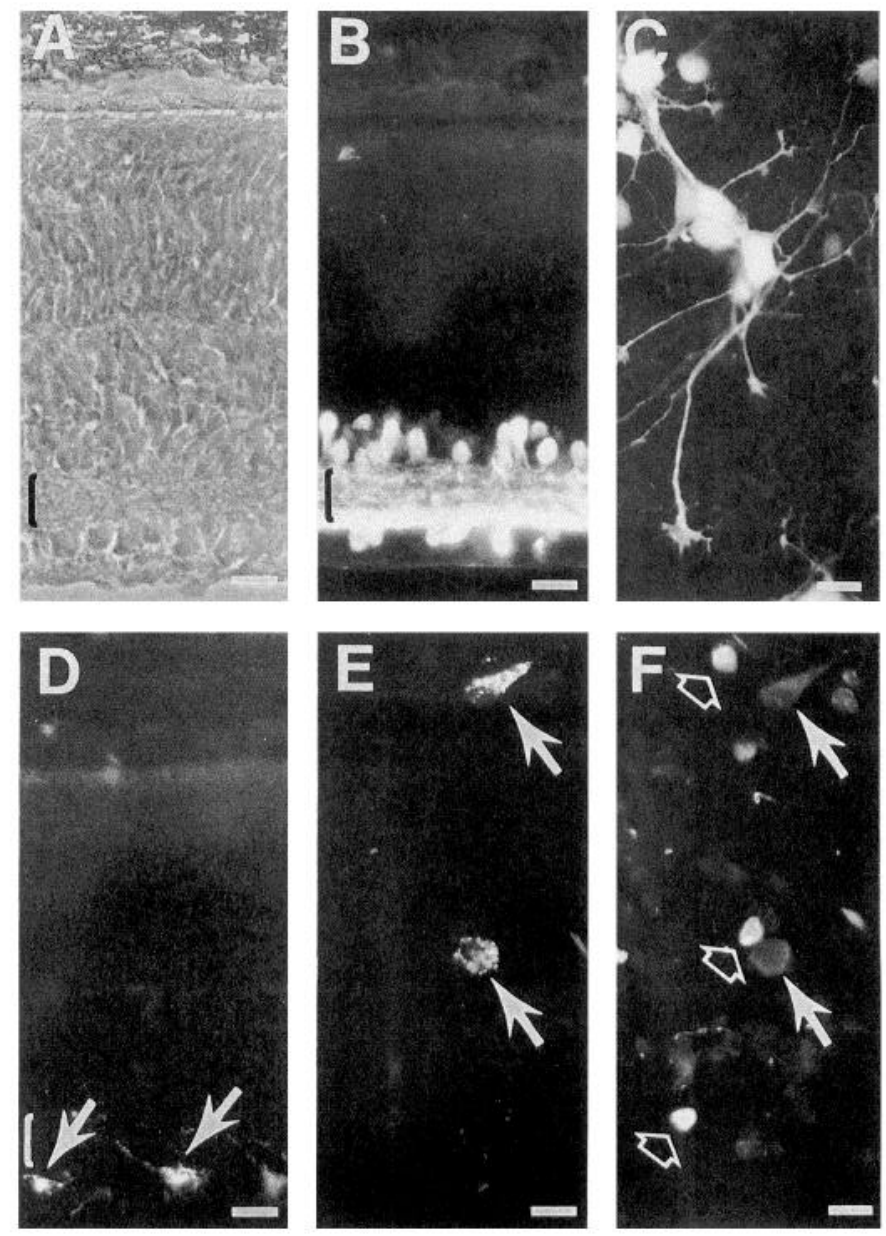

Figure 1. Immunoreactive-cellular retinoic acid binding protein (CRABP) in retinal sections and in tissue culture. Sections were derived from postnatal day 3 rat pups. Antibody to CRABP labels cell somata and processes exclusively within the inner plexiform layer ( $A$, phase; $B$, immunofluorescence). In culture the antibody labels cell somata and the full extent of any neurites including their growth cones $(C)$. In $C$, the retinal cells were plated at high density $(\sim 100,000$ cells per well 24-well plate) and are thus extending processes on to underlying retinal glial cells. CRABP-positive amacrine cells can be clearly distinguished from dissociated retinal ganglion cells in culture. Superior colliculus injections with dextran-rhodamine (10,000 MW; Molecular Probes, Eugene, OR) using postnatal day 3 rat pups, labels retinal ganglion cell bodies in the vitreal-most portion of the retina $(D$, arrows $)$. When these retinas are dissociated $24 \mathrm{hr}$ later, ganglion cells can be identified $(E)$ and distinguished from amacrine cells by their lack of CRABP labeling $(F)$. Solid arrows in $D-F$ indicate ganglion cells, and open arrows in $F$ indicate CRABP-positive amacrine cells. In five independent experiments in which dissociated cells were plated at 50,000 cells per well/ 24-well plate, no doubly labeled (CRABP/dextran-rhodamine) cells were observed $(N=220)$. Brackets in $A, B$, and $D$ indicate the inner plexiform layer. Scale bars: $A, B, D-F, 20 \mu \mathrm{m} ; C, 15 \mu \mathrm{m}$.

of many cell bodies within the ganglion cell layer (Fig. 1D). When these labeled retinas were dissociated and stained for CRABP, no examples were ever found of dextran-labeled cells that were also positive for the amacrine cell antibody (compare Fig. $1 E, F)$. In experiments in which RGC processes were examined, the monoclonal antibody against Thy-1.1 (Sarthy et al., 1983; Barnstable and Dräger, 1984) or NCAM was used to doubly label dextran-positive cells. These data demonstrate that amacrine cells and their neurites can be clearly identified and distinguished from RGC neurons and their processes in culture. 

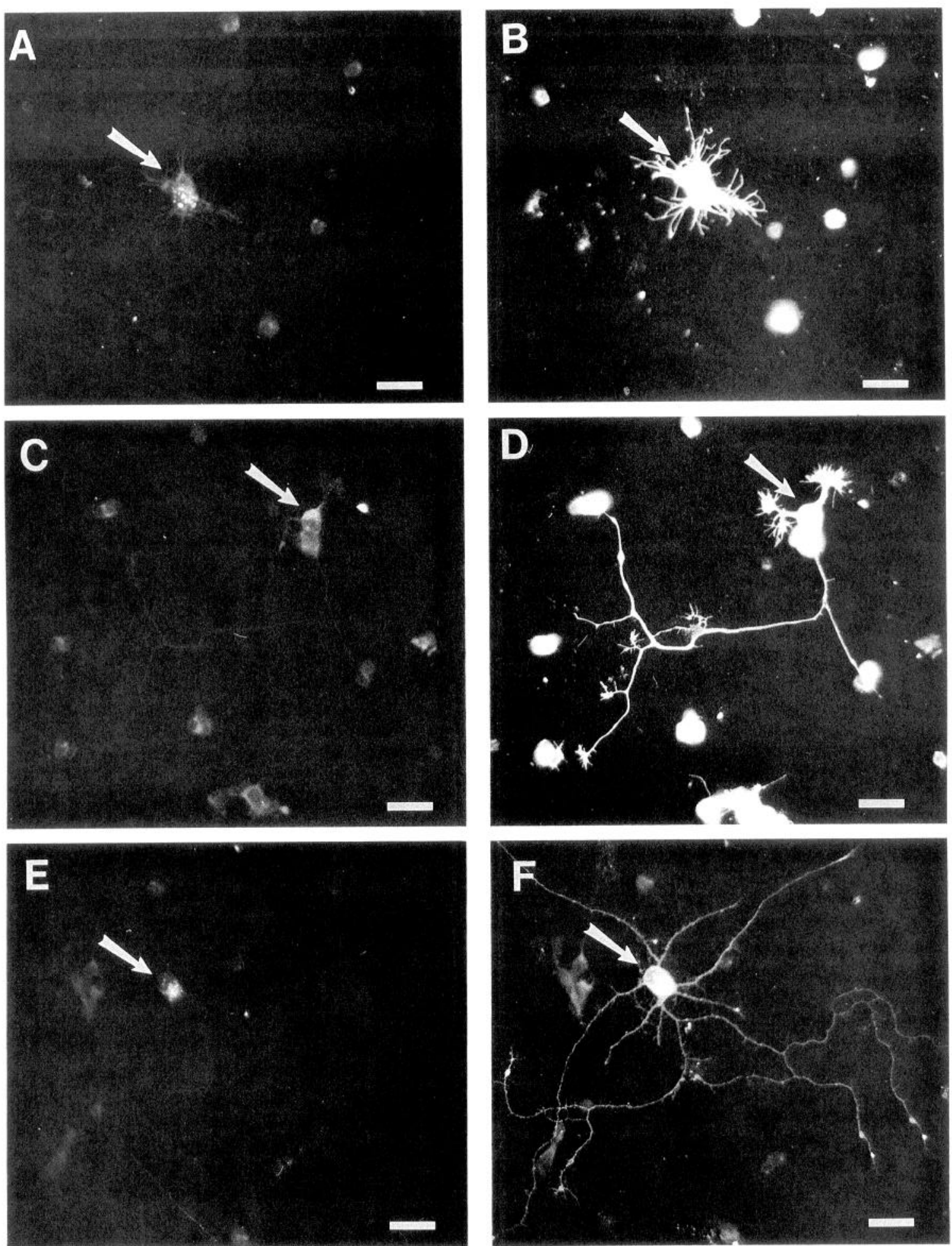

Figure 2. Retinal ganglion cells (dextran-rhodamine labeled following superior colliculus injections) from postnatal rat retina do not grow neurites on NCAM, but can extend long processes on L1 and N-cadherin. Dissociated retinal ganglion cells were plated at low density on to NCAM ( $A, B$ ), $\mathrm{Ll}(C, D)$ and N-cadherin $(E, F)$ substrates and subsequently stained with anti-Thy-1 or anti-NCAM antibodies to reveal the full extent of their processes. This figure shows the typical morphologies of ganglion cells isolated from P3 retina grown in culture for $18 \mathrm{hr}$. P10-derived ganglion cells morphologically appeared the same. Dextran-rhodamine filled cells were derived from postnatal day 2 rat pups allowed to survive for 24 hr after injections before culturing. $A, C$, and $E$ show the dextran-labeled cell bodies, while $B, D$, and $F$ show the corresponding images of the entire cells after being labeled with Thy-1 or NCAM $(A$, Thy-1; $D$, Thy-1; $F$, NCAM). Arrows indicate corresponding cell bodies of dextran-labeled and Thy-1 or NCAM stained cells. All of the ganglion cells on NCAM $(B)$ were either completely rounded up or extended small fibers in no particular orientation. Ganglion cells on L1 $(D)$ or N-cadherin $(F)$ grew extensive neurites. Scale bars, $25 \mu \mathrm{m}$. 
Rod photoreceptor cells were identified in culture by immunofluorescence using the monoclonal antibody Rho-4D2 directed against rhodopsin (Hicks and Barnstable, 1987). This antibody has been previously characterized in the developing and adult rat retina, labeling the entire photoreceptor cell layer from outer segments to rod synaptic terminals (Hicks and Barnstable, 1987). In culture, rhodopsin immunoreactivity is distributed throughout the entire cell somata and full extent of any neurites as described previously (Kljavin and Reh, 1991). We also ruled out the possibility that the number of rhodopsinimmunoreactive cells may differ depending on the substrate onto which the cells were plated, by determining that the percentage of immunoreactive cells on the different substrates was not significantly different (Table 1).

\section{Response of retinal neurons to the CAM substrates}

Postnatal retinal ganglion cells ( $R G C$ ). In a number of different studies, the role of adhesive molecules as neurite growth promoting factors for chick retinal ganglion cells has been examined (Neugebauer at al., 1988; Doherty et al., 1990, 1991; Drazba and Lemmon, 1990; Payne et al., 1992). In all these experiments, NCAM, L1, and N-cadherin were shown to regulate the growth of chick retinal ganglion cell neurites. However, similar studies using mammalian retinal ganglion cells has been described previously only for laminin (Cohen and Johnson, 1991). Therefore, in this study we also examined neurite outgrowth from dissociated postnatal rat retinal ganglion cells as a standard for comparison with postnatal amacrine and rod photoreceptor cells. Postnatal days 3 (P3) and 10 (P10) rat retina were used for these experiments and single isolated ganglion cells were identified as dextran-rhodamine filled cells as described above. The typical appearance of ganglion cells on NCAM, L1, and N-cadherin substrates after $18 \mathrm{hr}$ in culture is shown in Figure 2, $A$ and $B$, $C$ and $D$, and $E$ and $F$, respectively. On NCAM, ganglion cells derived from either age retina did not respond by significant growth of neurites. RGCs were either completely rounded up and free of neurites, or they displayed many small thin processes oriented in no particular direction (Fig. $2 A, B$ ). On L1 and N-cadherin substrates, RGCs grew extensive neurites as shown in Figure 2, $D$ and $F$.

The percentages of cells with neurites after $18 \mathrm{hr}$ in culture are quantified in Figure 3. None of the RGCs on NCAM had neurites greater than two cell body diameters, whereas approximately $50 \%$ (on L1) and $80 \%$ (on N-cadherin) grew neurites after $18 \mathrm{hr}$ in culture for either age of RGC. The majority of RGCs on L1 had only one or two neurites at either age; less than $10 \%$ of the ganglion cells on L1 had 3 or more primary neurites (Fig. $3 B$ ). This was in contrast to $\mathrm{N}$-cadherin, where we found that the majority of RGCs had at least three neurites, and up to $60 \%$ of the ganglion cells had four or more neurites. Mean neurite lengths of the longest primary neurite and the total neurite output for ganglion cells on L1 was between 200 and $250 \mu \mathrm{m}$ at either age (Fig. 3C). On N-cadherin, the length of the longest primary neurite grown by RGCs was similar to $\mathrm{Ll}$, in that they were never greater than $300 \mu \mathrm{m}$; however, the mean total neurite output on $\mathrm{N}$-cadherin was much greater than on $\mathrm{L} 1$, approximately $900 \mu \mathrm{m}$ for P3 and $650 \mu \mathrm{m}$ for P10derived retinal ganglion cells (Fig. 3C). As a control we also examined coverslips that were coated only with serum and found that virtually none of the ganglion cells grew neurites on these substrates (Fig. 3A).

Amacrine cells. Amacrine cells were examined at two post- natal ages, $3 \mathrm{~d}$ and 10-12 $\mathrm{d}$ after birth, because these are the ages when amacrine cells normally show their greatest neurite growth in vivo. By $3 \mathrm{~d}$, most or all of the amacrine cells have become postmitotic and most cells have begun to form diffusely branching processes within the prospective IPL (Morest, 1979). At 10-12 d, just before eye opening (about $14 \mathrm{~d}$ after birth), the majority of amacrine cells are nearing maturity and some are rapidly growing neurites horizontally as the inner plexiform layer expands. Figure 4 shows the typical morphology of dissociated amacrine cells, identified by staining with the antibody to CRABP, extending neurites after 18-24 hr in culture on NCAM $(A, B)$, L1 $(C, D)$, and N-cadherin $(E, F)$ from $\mathrm{P} 3(A, C, E)$, and $\mathrm{P} 12(B, D, F)$ retina. On all the substrates and at either age, some amacrine cells responded by growing extensive neurites.

Nevertheless, there were significant differences in the percent of amacrine cells that grew neurites on any particular CAM substrate. For example, whereas $86.4 \%$ of the amacrine cells extended neurites on $\mathrm{N}$-cadherin, only $45 \%$ of these cells grew neurites on NCAM and $11.4 \%$ on Ll substrates (Fig. $5 A$ ). In addition, we also found that the percentage of the amacrine cells with neurites on each substrate changed little over the subsequent $3 \mathrm{~d}$ in culture (NCAM, 57.3\%; L1, 10.5\%; N-cadherin, $90.1 \%$ ), suggesting that the differences do not reflect variations in growth rate on the substrates (Fig. 5A). The percentage of amacrine cells with neurites on the different substrates also changed little when different concentrations of the CAMs similar to other studies were used (Lagenaur and Lemmon, 1987; Bixby and Zhang, 1990) (Fig. 5A). For example, there were no significant differences between the percentage of amacrine cells with neurites on $\mathrm{L} /$ substrate concentrations ranging from 100 to 40 $\mu \mathrm{g} / \mathrm{ml}$ (Fig. 5A). Far fewer amacrine cells, however, grew neurites at concentrations of $20 \mu \mathrm{g} / \mathrm{ml}$. NCAM at concentrations ranging from 100 to $80 \mu \mathrm{g} / \mathrm{ml}$ also gave similar results; however, at 40 $\mu \mathrm{g} / \mathrm{ml}$ or less we found fewer cells with neurites. Amacrine cells continued to grow extensive neurites on $\mathrm{N}$-cadherin even when it was at $10 \mu \mathrm{g} / \mathrm{ml}$. On nitrocellulose coated coverslips without protein, amacrine cells did not grow neurites (Fig. $5 A$ ).

Figure 5, $B$ and $C$, shows the quantification of the number of primary neurites and the neurite lengths for amacrine cells on the different substrates. On NCAM the highest percentage (43.3\%) of the amacrine cells at P3 grew only one primary neurite (Fig. $5 B$ ). In contrast, the highest percentage of amacrine cells at P10 on this same substrate $(38.3 \%)$ had two primary neurites (Fig. $5 B$; see also Fig. $4 A, B$ ). In addition, we also observed that $\mathrm{P} 10$ amacrine cells on NCAM typically grew longer neurites (longest primary neurite averaged $69 \mu \mathrm{m}$ at $\mathrm{P} 3$ and $102 \mu \mathrm{m}$ at P10, and the mean total length of neurites at P3 was $88 \mu \mathrm{m}$ and at P10 was $179 \mu \mathrm{m})$. The majority of amacrine cells on L1 substrates at either age grew only one neurite (Fig. $5 B$ ), but the mean total neurite lengths were $113 \mu \mathrm{m}$ at P3 and $146 \mu \mathrm{m}$ at P10. Again, amacrine cells dissociated from older retina had longer neurites, but the difference on $\mathrm{L} 1$ was not as pronounced as that observed on NCAM. Similar to ganglion cells, N-cadherin stimulated the strongest neurite growth response; the highest percentages of amacrine cells had 2, 3, 4, or more primary neurites and the total neurite output (greater than $300 \mu \mathrm{m}$ for either age) was significantly greater on this substrate compared to NCAM or L1 (Fig. 5C).

Rod photoreceptor cells. Rod photoreceptor cells were dissociated from rat retinas at postnatal days 3 and 10 . At postnatal day 3 , the majority of rods become postmitotic (e.g., Sidman, 1961; Young, 1963), and those that are the most mature are 

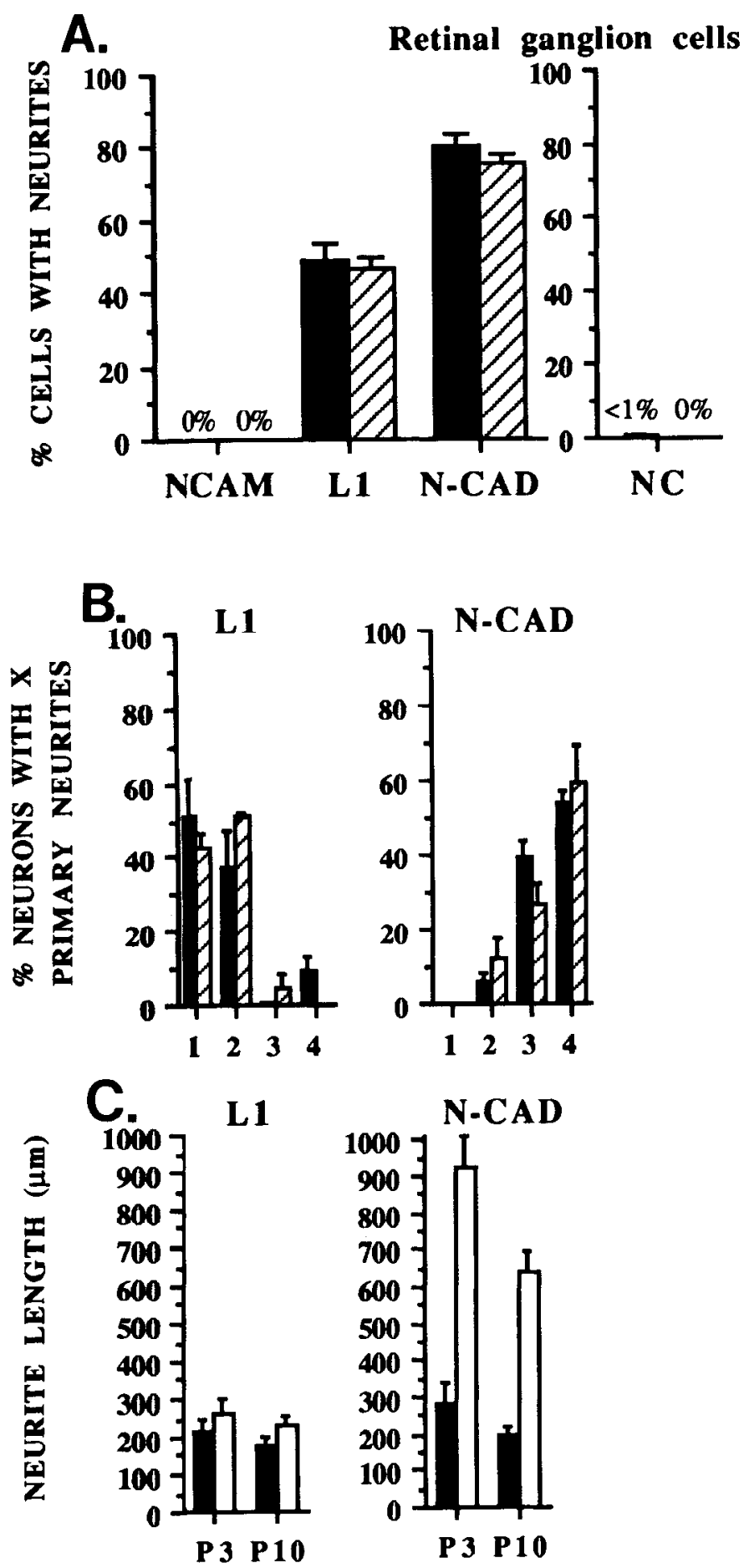

Figure 3. Graphs showing the ability of postnatal day 3 retinal ganglion cells (dextran-rhodamine labeled) to extend processes on NCAM, L1, and $\mathrm{N}$-cadherin. $A$, Percentage of cells with neurites longer than two cell body diameters after $18 \mathrm{hr}$ in culture (solid bars indicate P3-derived cells and the hatched bars indicate P10-derived cells). Ganglion cells identified in dissociated cultures after superior colliculus injections with dextran-rhodamine (compare $B$ ), did not respond to NCAM by growing processes, but did grow extensive neurites on L1 and N-cadherin. The graph labeled $N C$ refers to nitrocellulose coated coverslips that were blotted with serum only. Virtually none of the ganglion cells at either age grew neurites on serum coated coverslips. For each data point at least 100 cells were counted from five independent experiments and each experiment had no less than six coverslips. All values represent the mean \pm SE. $B$, Percentage of retinal ganglion cells (dextran-rhodamine labeled) with $X(1,2,3$, and 4 or more) primary neurites after beginning to form inner/outer segments and vitreally projecting processes. Rods derived from P10 retina have already grown neurites, developed outer segments and are in synaptic contact with other retinal neurons within the outer plexiform layer. Figure 6 summarizes the typical morphology of rods cultured for 18-24 hr on NCAM $(A-D), \mathrm{Ll}(E, F)$, and N-cadherin $(G$, $H)$ substrates after dissociation from $\mathrm{P} 3(A, E, G)$ and $\mathrm{P} 10(B-$ $D, F, H)$ retinas. Of all the substrates, NCAM was the only CAM that promoted substantial neurite outgrowth from rods, and this occurred mostly when rods were dissociated from P10 retinas. The majority of $\mathrm{P} 3$ rods on NCAM after $24 \mathrm{hr}$ were rounded up as shown in Figure $6 A$, in contrast to rods dissociated from $\mathrm{P} 10$ retina which grew long thin neurites (Fig. $6 B-$ $D)$.

Figure 7 summarizes the quantification of the percentage of rods with processes, number of primary neurites, and their neurite lengths. Less than $6 \%$ of the $\mathrm{P} 3$ rods on NCAM had neurites longer than two cell body diameters, whereas $40.7 \%$ of the rods dissociated at P10 had long neurites on NCAM after $24 \mathrm{hr}$ in culture (Fig. $7 A$ ). Most of the $\mathrm{P} 10$ rods responding to NCAM (about $60 \%$ ) had a single process (Fig. $7 B$ ), although some rods also displayed multiple processes as shown in Figure $6, C$ and $D$. The average length of the longest primary neurite grown by rods was about $60 \mu \mathrm{m}$ after $24 \mathrm{hr}$ in culture, with an average total neurite length of about $75 \mu \mathrm{m}$. Rods plated on $\mathrm{Ll}$ and $\mathrm{N}$-cadherin at either age remained mostly rounded up without any neurites (Figs. $6 A, 7 A$ ), which was also the case for rods plated onto nitrocellulose alone (Fig. $7 A$ ).

\section{Antibody perturbation of neurite growth on NCAM, LI, and $N$-cadherin}

The specificity of the neurite growth-promoting effect of the substrates was investigated in another series of experiments by culturing the retinal cells on the CAM substrates in the presence of blocking antibodies. For these experiments, amacrine and rod photoreceptor cells were specifically identified as described above. Prior to plating the cells on to the substrates, blocking antibodies to NCAM, L1, or N-cadherin were added for 2-3 hr at $37^{\circ} \mathrm{C}$. As shown in Table 2 , preincubating the CAM substrates with their corresponding antibodies dramatically decreased the number of both amacrine cells and rods with neurites greater than two cell body diameters. Preincubating the substrates with noncorresponding antibodies had no significant effect on the number of cells with neurites on the different substrates.

\section{Immunolocalization of $N C A M, L 1$, and $N$-cadherin in the postnatal rat retina}

As a reference to the results presented here, the immunolocalization of NCAM, L1, and N-cadherin was investigated in the sectioned postnatal rat retina at developmental periods corre-

$18 \mathrm{hr}$ in culture. Solid bars in the graphs representing the data for L1 and $\mathrm{N}$-cadherin indicate P3-derived cells and the hatched bars indicate P10-derived cells. At least 100 cells with neurites from three independent experiments were examined for each data point. All values represent the mean $\pm \mathrm{SE}$. $C$, Neurite length measurements presented in micrometers after $18 \mathrm{hr}$ in culture for P3- and P10-derived ganglion cells plated on to the different substrates. The solid bars indicate lengths of the longest primary neurite, and the open bars indicate total neurite output. At least 100 cells with neurites from three independent experiments were used to derive the lengths at each data point. All values represent the mean $+\mathrm{SE}$. 

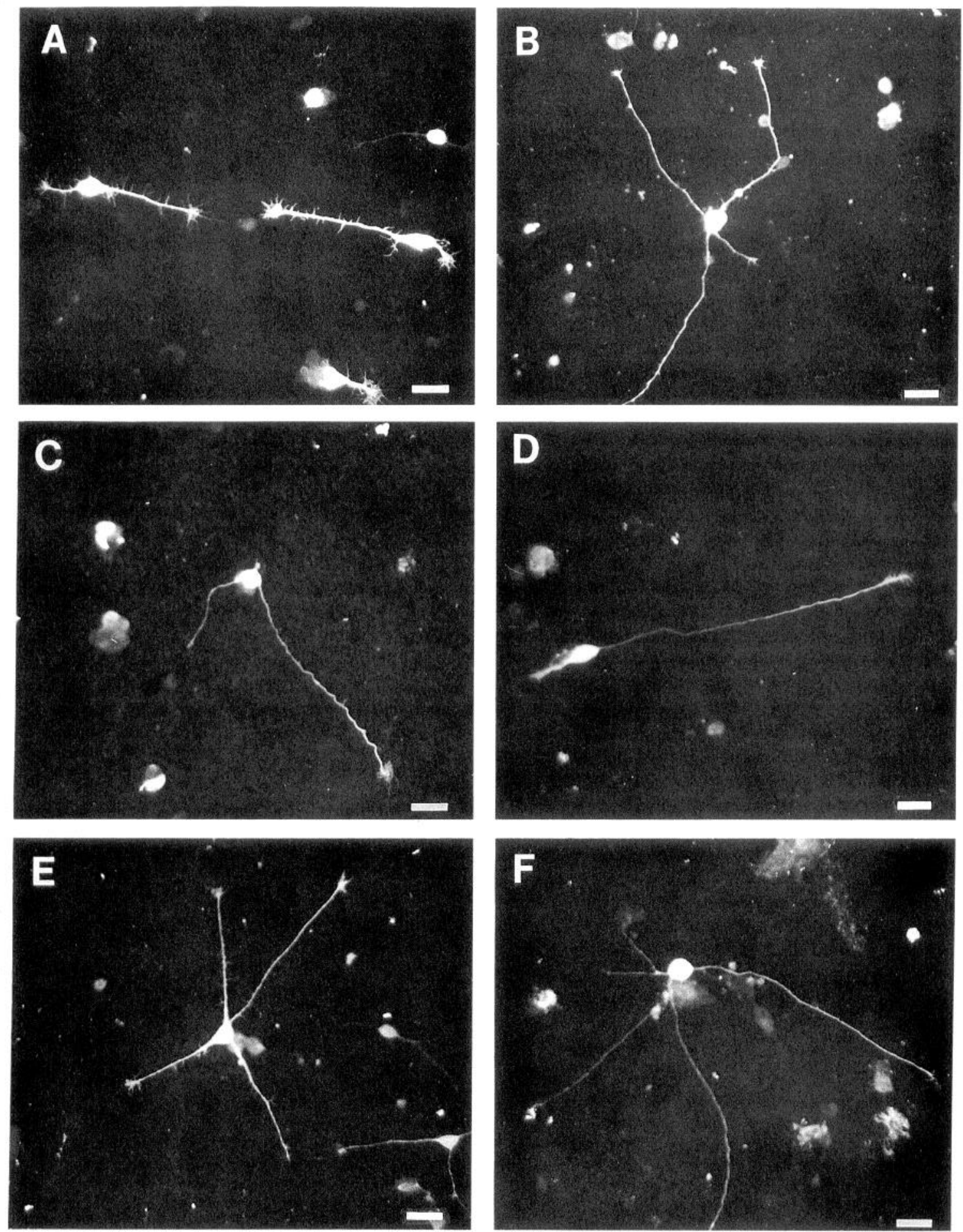

Figure 4. Amacrine cells can extend neurites on NCAM, L1 and N-cadherin. Amacrine cells in this figure were identified in culture using the monoclonal antibody CRABP as described in the Materials and Methods and Results. The micrographs show the typical appearance of dissociated amacrine cells from $\mathrm{P} 3(A, C, E)$ and $\mathrm{P} 12(B, D, F)$ rat retina on $\mathrm{NCAM}(A, B), \mathrm{L} 1(C, D)$, and N-cadherin $(E, F)$ substrates after 24 hr in culture. On any of the substrates at either age, amacrine cells grew extensive neurites. Scale bars, $15 \mu \mathrm{m}$.

sponding to the ages of the cultured cells. Other localization studies have been done in chick and mouse retina using different ages, but showing essentially similar localization patterns $(\mathrm{Ru}-$ tishauser et al., 1978; Thiery et al., 1985; Daniloff et al., 1986; Hatta and Takeichi, 1986; Lemmon and McLoon, 1986; Matsunaga et al., 1988b). The antibodies used for the present ex- periments were affinity-purified polyclonal serum to NCAM and Ll (Chung et al., 1991), and a polyclonal serum generated against an $\mathrm{N}$-cadherin fusion protein previously characterized (Doherty et al., 1991).

Figure 8 shows that at P3 $(A-C)$ or P10 $(E-G)$, immunoreactivity for all three CAMs was present in the neural retina 
Figure 5. Graphs showing the ability of amacrine cells to extend processes on NCAM, $\mathrm{L} 1$, and N-cadherin. $A$, Percentage of amacrine cells with neurites longer than two cell body diameters after $24 \mathrm{hr}$ in culture unless otherwise indicated (numbers below the bars indicate the following: $1, \mathrm{P} 3,2, \mathrm{P} 10 ; 3, \mathrm{P} 3$, $3 \mathrm{~d}$ in vitro; 4, CAM concentration 100 $\mu \mathrm{g} / \mathrm{ml} ; 5$, CAM concentration $40 \mu \mathrm{g} / \mathrm{ml}$ for NCAM and $\mathrm{LI}$, and $10 \mu \mathrm{g} / \mathrm{ml}$ for $\mathrm{N}$-cadherin; 6, CAM concentration 20 $\mu \mathrm{g} / \mathrm{ml}$. The dash in place of a bar indicates experiment not done. Amacrine cells in dissociated cultures grew neurites on all three substrates; however, there were significant differences in the percentage of the cells that responded to each substrate [pairwise comparisons examining P3 (1) or P10 (2) using the Student's $t$ test $P<0.001]$. The graph labeled $N$ refers to nitrocellulose coated coverslips that were blotted only with serum. None of the amacrine cells at either age grew neurites on serumcoated coverslips. For each data point at least 100 cells were counted from five independent experiments, and each experiment had no less than six coverslips. All values represent the mean \pm the SE. $B$, Percentage of amacrine cells with one, two, three, and four or more primary neurites greater than two cell body diameters after $24 \mathrm{hr}$ in culture. Solid bars indicate P3-derived cells and the hatched bars indicate P10-derived cells. At least 100 cells with neurites from three independent experiments were examined for each data point. All values represent the mean \pm the $\mathrm{SE} . C$, Neurite length measurements presented in micrometers after $24 \mathrm{hr}$ in culture for P3- and P10-derived amacrine cells plated on to the different substrates. The solid bars indicate lengths of the longest primary neurite, and the open bars indicate total neurite output. At least 100 cells with neurites from three independent experiments were used to derive the lengths at cach data point. All values represent the mean $\pm \mathrm{SE}$.
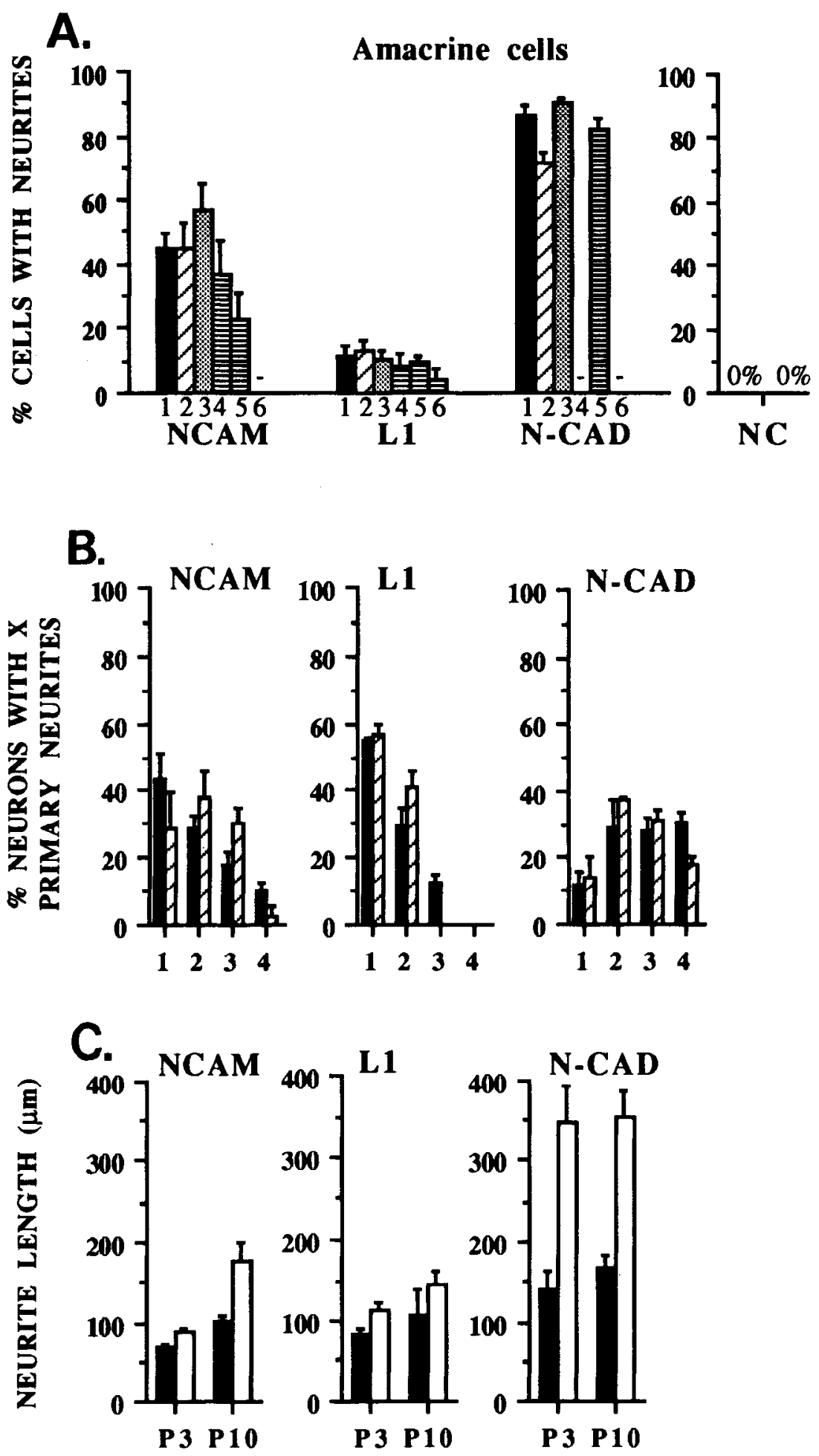

of the rat, but that each shows a unique distribution. Immunoreactive NCAM (Fig. $8 A, E$ ) at either age was found diffusely throughout all retinal layers, but appears more intense in the IPL and ganglion cell fiber layer. Immunoreactive Ll (Fig. $8 B, F$ ) was primarily localized to the IPL where amacrine cell processes are growing and also within the ganglion cell fibcr laycr at cither age. However, L1 immunoreactivity was not uniformly distributed throughout the IPL, but was most conspicuous as two lightly labeled bands at P3 that increased in labeling intensity by $\mathrm{P} 10$ (Fig. $8 F$ ). N-Cadherin immunoreactivity (Fig. $8 C, G$ ) was uniform in distribution throughout all retinal layers, although with increasing age, the ganglion cell fiber layer, IPL, and outer limiting membrane (the contact junction between photoreceptor-photoreceptor and photoreceptor and Müller cclls) was most hcavily labeled. Since amacrine cells make up a diverse population of cells that project their fibers within the IPL either diffusely or restricted to certain strata (in transverse sections strata appear as bands within the IPL), the restricted 

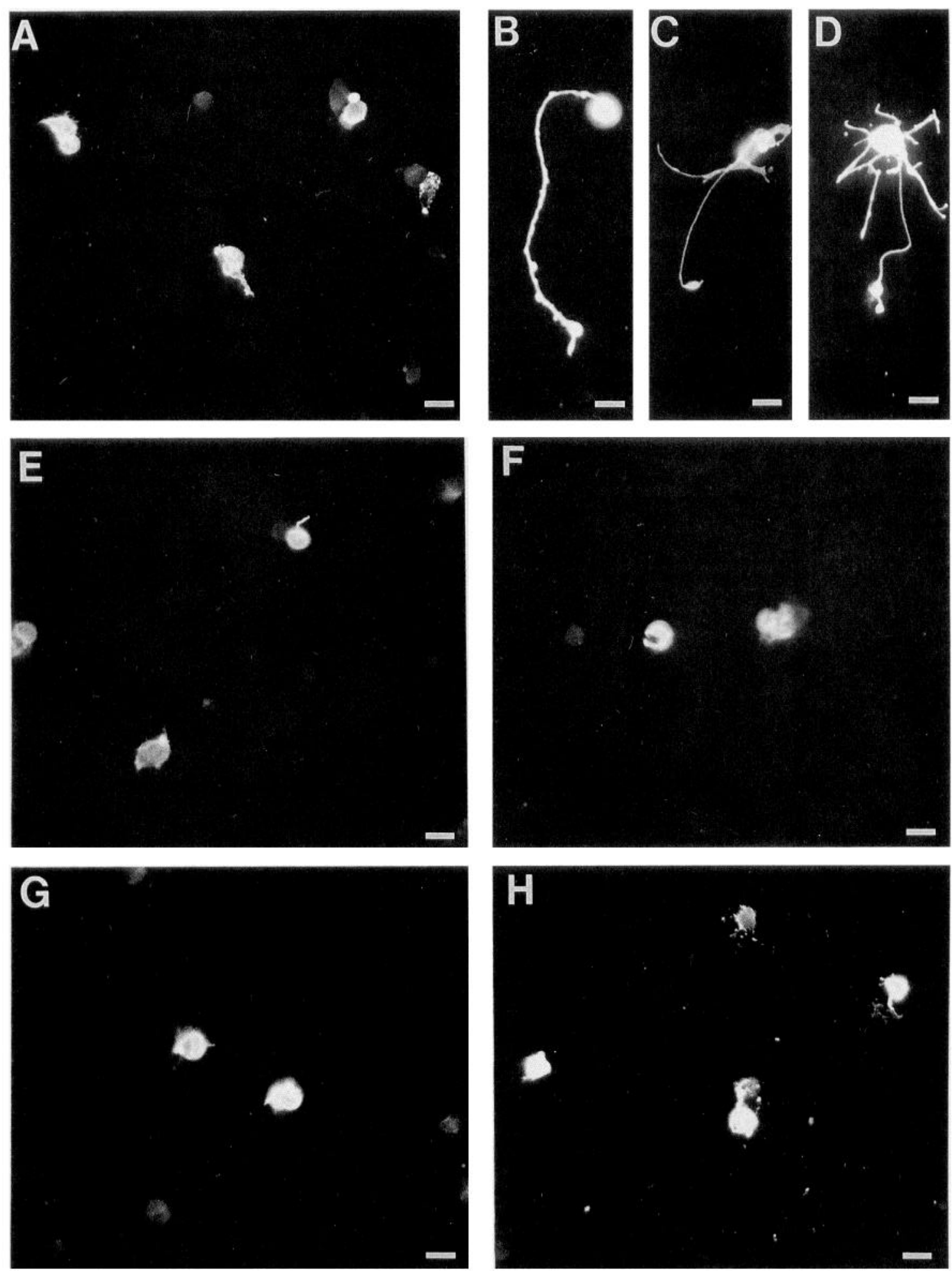

Figure 6. Of the substrates tested, rod photoreceptor cells grew neurites only when in contact with NCAM, and mostly when dissociated from P10 (but not P3) retina. The micrographs show the typical morphology of dissociated rod photoreceptor cells derived from postnatal day 3 ( $A$, $E$, $G)$ and postnatal day $10(B-D, F, H)$ rat retinas plated onto NCAM $(A-D), \mathrm{Ll}(E, F)$, and N-cadherin $(G, H)$. Rods were identified with the monoclonal antibody Rho-4D2 directed against rhodopsin. On any of the substrates, rods grew neurites only in response to NCAM $(B-D)$. The majority of single isolated P10 rods on NCAM appeared as in $B$ and $C$, with one or more thin neurites. However, some P10 rods had multiple neurites as shown in $D$. In contrast, the majority of rods from P3 retina plated onto NCAM did not grow neurites $(A)$. On any of the other substrates tested, rods derived from either age also typically did not grow neurites. Scale bars, $20 \mu \mathrm{m}$. 

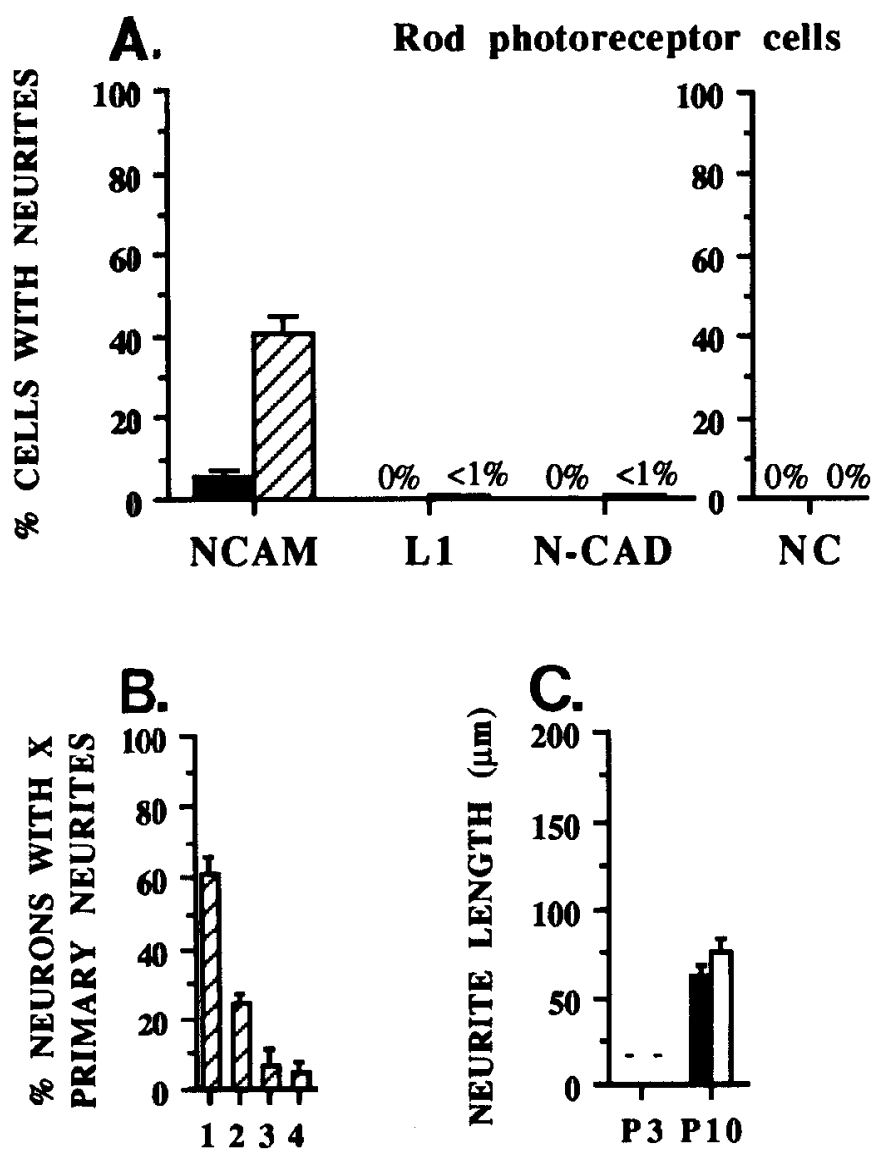

Figure 7. Graph of the ability of rod photoreceptor cells to extend neurites on NCAM, L1, or N-cadherin. $A$, Percentage of rods with neurites longer than two cell body diameters after $24 \mathrm{hr}$ in culture. Rods were analyzed after isolation at two ages: postnatal day 3 (solid bars) and postnatal day 10 (hatched bars). Rods grew long neurites on NCAM, but mostly when dissociated from P10 animals. Far fewer, less than 6\% of the P3-derived rods plated onto NCAM grew neurites. Fewer than $1 \%$ of the rods grew neurites on any of the other substrates. $N C$ refers to nitrocellulose coverslips coated with serum only. None of the rods grew neurites on the serum coated substrate. For each data point at least 100 cells were counted from five independent experiments and each experiment had no less than six coverslips. All values represent the mean $\pm \mathrm{SE}$. $B$, Percentage of rod photoreceptor cells with one, two, three, and four or more primary neurites greater than two cell body diameters after $24 \mathrm{hr}$ in culture on the NCAM substrates. Measurements were made for P10-derived rods only (hatched bars). At least 100 cells with neurites from three independent experiments were examined. All values represent the mean $\pm \mathrm{SE}$. $C$, Neurite length measurements presented in micrometers after $24 \mathrm{hr}$ in culture for P10-derived rod photoreceptor cells plated onto NCAM substrates. The solid bars indicate lengths of the longest primary neurite, and the open bars indicate total neurite output. At least 100 cells with neurites from three independent experiments were used to derive the length data. The dash in place of the bars represents experiment not done. All values represent the mean $\pm \mathrm{SE}$.

Ll staining pattern in the IPL suggests that not all amacrine cells are immunoreactive for this CAM. Consistent with this possibility, we found that not all CRABP-positive amacrine cells were immunoreactive for $\mathrm{Ll}$ when analyzed in high density cultures as shown in Figure 9.

\section{Discussion}

NCAM, I 1, and N-cadherin are known to be important cell adhesion molecules for promoting the growth of axons from the
Table 2. Neurite growth on the CAM substrates after addition of blocking antibodies

\begin{tabular}{lrll} 
& \multicolumn{2}{l}{ Substrate } & \\
\cline { 2 - 4 } Blocking Antibody & \multicolumn{1}{c}{ NCAM } & L1 & N-CAD \\
\hline Amacrine Cells & & & \\
NCAM & $4.4(1.2)$ & $96.5(3.4)$ & $100.0(3.1)$ \\
L1 & $98.4(8.1)$ & 0 & $101.0(1.7)$ \\
N-CAD & $102.4(3.1)$ & $113.0(1.5)$ & $13.5(4.4)$ \\
Rod photoreceptor cells & & & \\
NCAM & $9.5(1.9)$ & - & - \\
L1 & $97.0(5.2)$ & - & - \\
N-CAD & $105.1(2.2)$ & - & -
\end{tabular}

Preincubating the CAM substrates with corresponding blocking antibodies significantly inhibited the growth of amacrine and rod photoreceptor cell neurites. Preincubating with noncorresponding antibodies had virtually no effect. Retinal cultures wre done as described for Table 1, except that prior to plating, monovalent antibodies to NCAM $(1 \mathrm{mg} / \mathrm{ml}), \mathrm{Ll}(1 \mathrm{mg} / \mathrm{ml})$, and monoclonal NCD-2 purified from ascities $(1 \mathrm{mg} / \mathrm{ml})$ were preincubated on corresponding and noncorresponding CAM-coated coverslips. Postnatal day 3 retinal cells were cultured for $24 \mathrm{hr}$ and amacrine cells and rod photoreceptor cells were identified as described above At least 100 cells from three independent experiments were used to derive the data at each point. Data are presented as the percentage of control with SEM (control: percentage of the postnatal day 3 amacrine cells and rods responding to the substrates given in Figs 6A, 8A).

retinal projection neuron, the ganglion cell, at least in vitro (Matsunaga et al., 1988; Doherty et al., 1990a,b; Drazba and Lemmon, 1990). All three of these molecules are known to mediate growth cone-substrate interactions via a homophilic binding mechanism, where each can bind to itself and is located both on the growth cone and on the cellular substrate that it contacts (Rutishauser et al., 1982; Nose and Takeichi, 1986; Lemmon et al., 1989). In the present study, we used purified protein samples of NCAM, L1, and N-cadherin that were "blotted" onto nitrocellulose-coated coverslips, and dissociated retinal cells were subsequently plated onto them at low density. In this way, single isolated retinal neurons could be examined when in contact exclusively with a single CAM as a substrate. Our data show that at least some of these same three cell adhesion molecules were found to stimulate neurite outgrowth from two classes of retinal nonprojection neurons, amacrine cells, and rod photoreceptor cells. However, the effectiveness of any particular CAM was dependent on the cell type and developmental period. At postnatal day 3, NCAM supported neurite growth only from amacrine cells, while I 1 and $\mathrm{N}$-cadherin promoted neurite growth from amacrine cells as well as ganglion cells, but not rods. At postnatal day 10, NCAM promoted the growth of amacrine cell neurites, and additionally, neurites from rod photoreceptor cells. $\mathrm{L} 1$ and $\mathrm{N}$-cadherin promoted neurite growth from both ganglion and amacrine cells, but not rods at this later postnatal age.

\section{Postnatal retinal ganglion cells extend neurites on $L I$ and $N$-cadherin}

Retinal ganglion cells are one of the first cell types to become postmitotic in the vertebrate retina, around embryonic day 13 in the rat (Sidman, 1961; Young, 1963). At the earliest stages in their development, RGC's send their axons into the ganglion cell fiber layer towards the optic nerve exit (e.g., Morest, 1970). As a standard for comparison both to other studies on RGCs, and to our study on amacrine and rods, we examined the response of RGCs dissociated from postnatal rat retina. At this time most of the ganglion cells have already grown axons out 

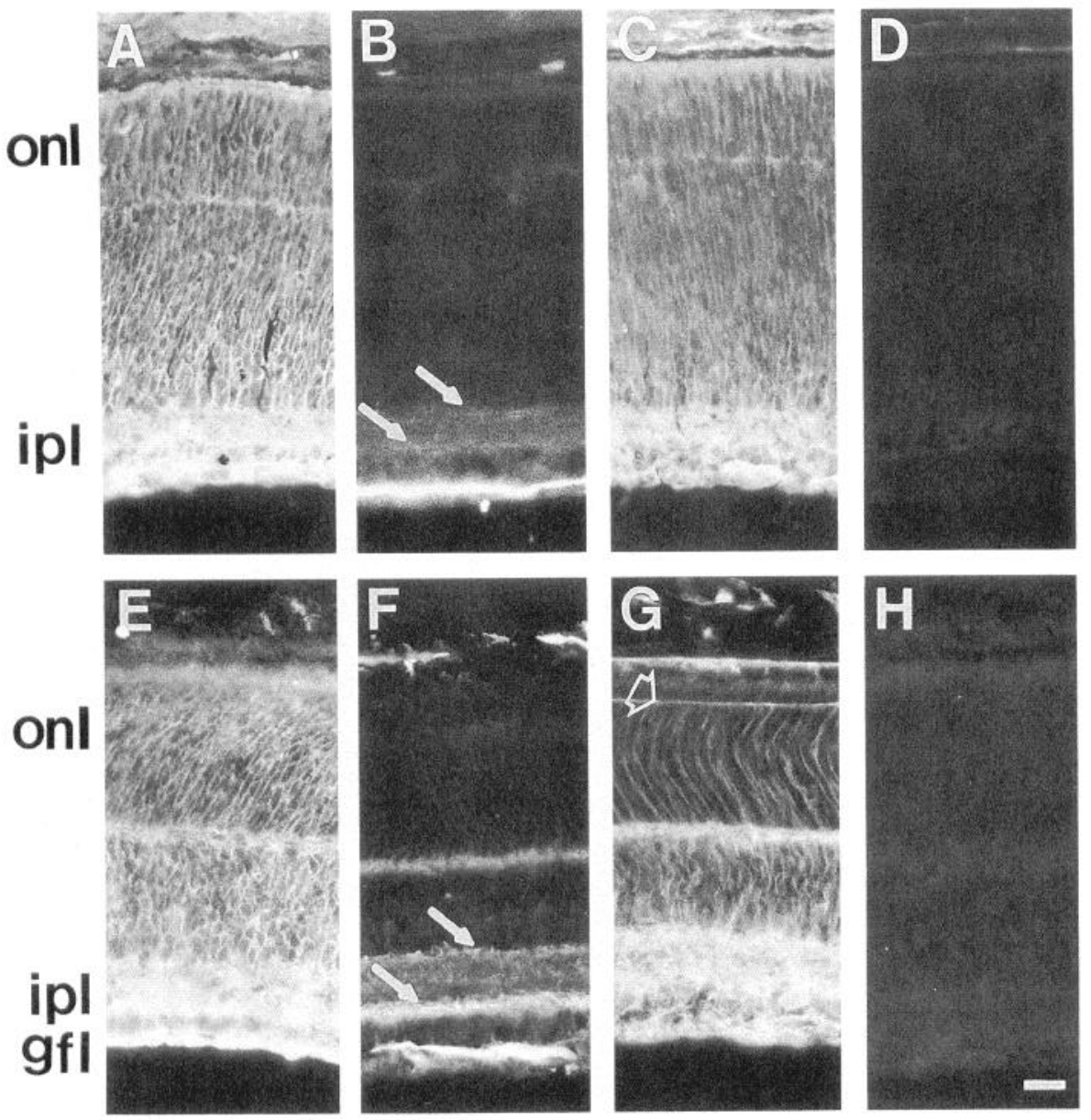

Figure 8. NCAM, L1, and N-cadherin are present within the rat retina corresponding to the ages of the cultured cells examined in the present study. Immunolocalization of NCAM $(A, E), \mathrm{L} 1$ $(B, F)$, and $\mathrm{N}$-cadherin $(C, G)$ in rat retinas derived from postnatal day 3 $(A-C)$ and postnatal day $10(D-F)$ were cryosectioned and analyzed immunohistochemically. onl, outer nuclear layer; $i p l$, inner plexiform layer; $g f l$, ganglion cell fiber layer. The arrows in $B$ and $F$ indicate the most intensely stained bands (strata) of Ll immunoreactivity within the IPL. The arrow in $G$ indicates $\mathrm{N}$-cadherin immunoreactivity within the outer limiting membrane, the contact junction between photoreceptor-photoreceptor and photoreceptorMüller cells. $D$ and $H$ are control retinal sections incubated only with a rabbitFITC secondary antibody. Scale bar (shown in $H$ ), $15 \mu \mathrm{m}$ for all micrographs.

of the retina to the brain as well as dendrites within the inner plexiform layer. We found that postnatal RGCs grew extensive neurites on L1 and N-cadherin, but did not respond to NCAM. Presumably, the lack of growth by postnatal rat RGCs on NCAM is similar to the loss of responsiveness that chick RGCs show during their development, at about the time when their axons have reached the tectum (Rager, 1980; Doherty et al., 1990a). All of the rat RGCs that failed to grow on NCAM in the present study were identified in culture after being labeled by collicular injections of dextran-rhodamine, and therefore most likely represent the most mature cells.

\section{Amacrine cells extend neurites in response to NCAM, LI, and $N$-cadherin}

Amacrine cells are the major class of retinal interneurons that begin to differentiate soon after RGCs (Sidman, 1961; Young, 1963). At the earliest times in their differentiation, amacrine cells extend their processes perpendicular to the scleral-vitreal axis of the retina, extending exclusively within the inner plexiform layer (Perry and Walker, 1980; Perry et al., 1983). In the present study, all three cell adhesion molecules, NCAM, L1 and $\mathrm{N}$-cadherin, promoted neurite outgrowth from amacrine cells dissociated from either early or late postnatal ages. This suggests that these CAMs may be important for regulating the growth of amacrine cell processes within the IPL during development.

Amacrine cells differed significantly in the percentage of cells that responded to the three CAMs. The greatest differences were seen between $\mathrm{Ll}$ and $\mathrm{N}$-cadherin, to which $11.4 \%$ and $86.4 \%$ of the amacrine cells, respectively, responded; in contrast, approximately $45 \%$ of the amacrine cells responded to NCAM. Even after several days in culture, we noted that the percent differences were still significant, suggesting that differential neurite growth rates on the different substrates was not a major factor in this finding. The differences in the number of amacrine cells growing neurites on the different substrates is not entirely surprising in light of the fact that amacrine cells as a group make up a large variety of functionally distinct subpopulations. Amacrine cells are diverse neurochemically (e.g., Marc, 1985; Rodieck, 1988; Crooks and Kolb, 1992) as well as morphologically in their dendritic projections (Boycott and Dowling, 1969; Kolb et al., 1981; Rodieck, 1988). In the rat, nine morphologically distinguishable types have been seen in Golgi preparations (Perry and Walker, 1980), and it is likely that a detailed immunohistochemical survey would reveal additional subtypes. Various populations of amacrine cells, therefore, may also differ with respect to the adhesive molecules, both in type and in functional form, that they express on their cell surfaces. Our observation that L1 immunoreactivity was restricted to only two or three strata within the IPL, and present on only a subpopulation of amacrine cells in vitro is consistent with this idea.

The differential expression of CAMs on amacrine cell surfaces could be, at least in part, the molecular basis for the large variety of shapes and dendritic field sizes that amacrine cells display. In an oversimplified description, amacrine cells could fit in at 

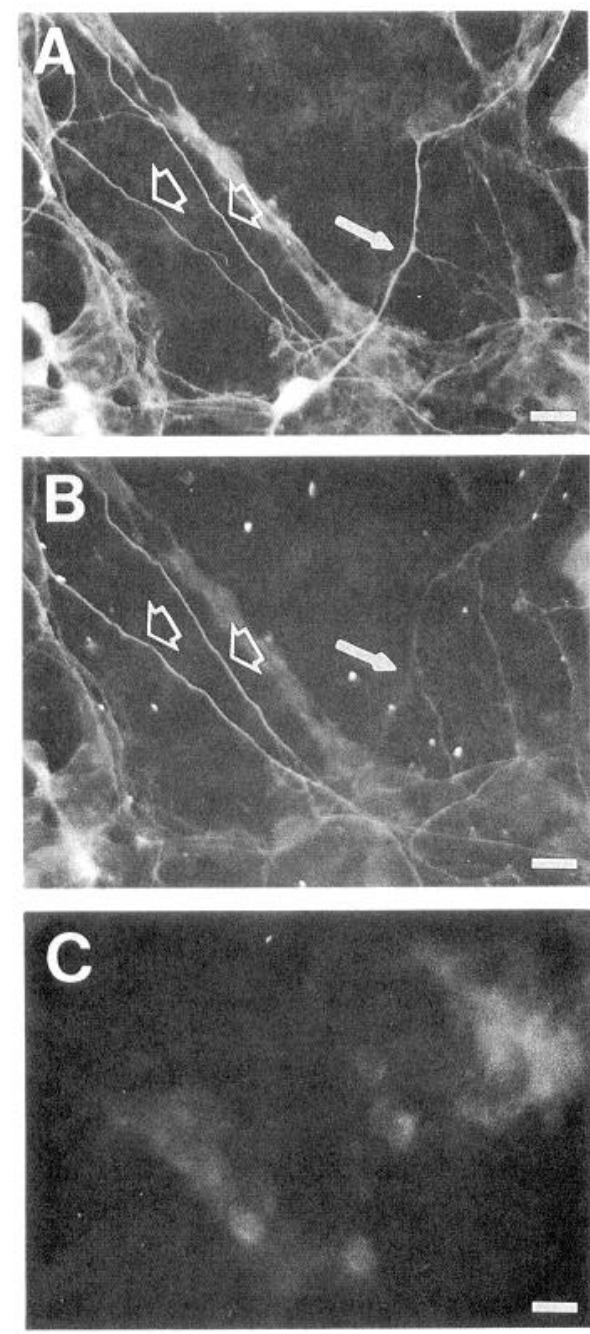

Figure 9. Only a subpopulation of amacrine cells in culture are immunoreactive for L1. Retinal cultures were plated at high density $(100,000$ cells $/ \mathrm{ml}, 24$-well plate) onto laminin-coated coverslips and maintained in culture for $2 \mathrm{~d}$. Double label immunolocalization of L1 and CRABP in these cultures shows that some amacrine cells are immunoreactive for L1, while others are not. In these high density cultures the amacrine cells are growing neurites onto the surfaces of underlying retinal glial cells. In $A$, the culture was stained with anti-CRABP, and $B$ shows the corresponding view stained with anti-L1. The micrograph in $C$ shows a similar culture incubated only with a rabbit-FITC secondary antibody. The open arrows in $A$ and $B$ indicate doubly labeled L1- and CRABPimmunoreactive neurites, and the solid small arrows indicate the CRABPpositive amacrine cell not immunoreactive for $\mathrm{Ll}$.

least two major morphological groups, large field and narrow field amacrine cells, owing to their range of dendritic projections throughout the IPL. For example, several studies have shown morphologically that multiple axon-bearing amacrine cell types exist which project their processes considerable distances within the IPL (Catsicas et al., 1987; Dacey, 1989; Famiglietti, 1992; see also Vaney et al., 1988). Other amacrine cells, however, project highly branched small dendritic projections covering an area only several micrometers in diameter (e.g., Perry and Walker, 1980; Rodieck, 1988). L1 is usually present on axonal surfaces projecting into long fiber tracts, and not on cell bodies or dendrites (Lemmon and McLoon, 1986). Amacrine cells expressing and responding to $\mathrm{L} 1$, therefore, may be among the population of cells with long axon-like projections. Those ama- crine cells expressing only molecules such as NCAM or N-cadherin may be among the population of cells with smaller, highly branched morphologies, since these CAMs are more generally distributed throughout the IPL.

The differential responsiveness and restricted localization of CAMs may be the molecular basis for the stratified synaptic organization within the IPL. The IPL is made up of processes from ganglion, bipolar, and amacrine cells, which form highly complex and stereotyped patterns of neuronal connectivity. Part of the complexity lies in the fact that certain amacrine cell subtypes are known to ramify among, and synapse with specific target cell groups within distinct "levels" or strata of the IPL (e.g., Perry and Walker, 1980; Marc, 1986; Rodieck, 1988). When neurochemically distinct amacrine cells are identified and examined in transverse sections of the retina, strata appear as bands, which are formed by the accumulations of nerve fibers organized into four or five distinct layers within the IPL. The selection of the strata into which an amacrine cell projects into may depend, at least in part, on adhesive molecules that can guide amacrine cell growth cones along specific pathways. There are many CAMs and extracellular matrix molecules that have been implicated in providing important cues for axon guidance, largely based on their restricted patterns of localization in vivo, and their ability to promote neurite growth in vitro. This group of CAMs includes Ll (Persohn and Schachner, 1987; Martini and Schachner, 1988; Rutishauser and Jessell, 1988; Bartsch et al., 1989), neurofascin (Rathjen et al., 1987), Tag-1/Axonin-1 (Dodd et al., 1988; Stoeckli et al., 1991), P84 (Chuang and Lagenaur, 1990), F3 (Durbec et al,, 1992), DM-GRASP/SC1/ JC7 (Burns et al., 1991; Tanaka et al., 1991; el-Deeb et al., 1992), and the invertebrate fasciclins I, II, and III (Bastiani et al., 1987; Patel et al., 1987). They are thought to be involved in the selective guidance of growth cones along preexisting nerve fibers, thus forming nerve fiber tracts destined for a distant target area. Several experiments, both the present data and earlier studies using affinity-purified $\mathrm{Ll}$ as a culture substrate, have shown that L1 can directly promote neurite outgrowth (Lagenaur and Lemmon, 1987; Lemmon et al., 1989). In the rat retina, similar to other species (chicken, Thiery et al., 1985; Lemmon and McLoon, 1986; fish, Blaugrund et al., 1992), we found that L l was restricted to two or three strata within the IPL depending on the age of the retina. Therefore, it is possible that $\mathrm{L} 1$, and other similarly functioning molecules may provide the appropriate molecular cues for directing certain amacrine cell fibers to their appropriate strata, and ultimately to appropriate target cell groups.

A similar function for NCAM and N-cadherin may be harder to discern solely on the basis of their immunohistochemical distributions within the IPL. At least within the limits imposed by the antibodies and immunofluorescent technique used in the present studies, both NCAM and N-cadherin immunoreactivity in the IPL appeared diffusely distributed. For both of these CAMs this is typical, as throughout the nervous system they are more widespread than $\mathrm{Ll}$, and are thought to function in general cell-sorting and neurite growth-promoting roles rather than guidance (e.g., Grunwald et al., 1982; Hoffman et al., 1986; Matsunaga et al., 1988b; Rutishauser, 1988). However, NCAM and $\mathrm{N}$-cadherin have been shown to mediate neurite-neurite interactions (e.g., Drazba and Lemmon, 1990), and even small changes in concentration of these CAMs can regulate whether and to what degree a neuron responds (Doherty et al., 1991). Therefore, whether these CAMs participate in directing some 
amacrine cells to certain strata, can not be decided. It should be interesting to determine what amacrine cell subtypes are responding to the particular CAMs, and/or what other adhesive molecules may be expressed in a cell type specific manner.

\section{Growth of rod photoreceptor cell neurites in vitro is regulated} by NCAM, but not LI or N-cadherin

Rod photoreceptor cells are one of the last cell types to become postmitotic in the developing retina (Sidman, 1961). During rod morphogenesis within the intact retina, the photopigment containing apparatus of the cell, the outer segment, appears to differentiate first as thickened "growth-cone looking" protrusions cxtending in the sclcral direction. From the vitreal surface of the cell body, thin short neuritic fibers begin to project in a vitreal direction towards the outer plexiform layer (Olney, 1968; Morest, 1970; Hinds and Hinds, 1979). In the present studies, rod photoreceptor cells grew neurites only on NCAM substrates but not on L1 or N-cadherin. Without further study by either morphological criteria (i.e., lamellar disk formation), or biochemical analysis, we are unable to say if outer segments had formed in our cultures; however, on some of the dissociated rods, there were conspicuous thickened protrusions immunoreactive with peripherin, which is normally associated only with the outer segment (Connell and Molday, 1990) (data not shown).

The response of rods on NCAM was developmentally regulated, in that rods dissociated from $\mathrm{P} 10$ but not $\mathrm{P} 3$ retina grew neurites. This result appears to be a general trend for early postnatal rod photoreceptor cells in culture plated onto pure substrates; in earlier studies we found that various extracellular matrix molecules, including laminin, also did not stimulate rod neurite growth (Kljavin and Reh, 1991). However, cultured P3 rod photoreceptor cells are capable of extending neurites on Müller glia, suggesting that their lack of growth seen again in this study does not reflect a general inability of early postnatal rods to form processes in culture. The limited growth response from P3 rod photoreceptor cells on NCAM was somewhat surprising, in light of the fact that NCAM is present on most, if not all cells within the retina, including the photoreceptor cell layer at the ages studied in the present work (Bartsch et al., 1990; Fig. 9 in the present study).

Why did the majority of $\mathrm{P} 3$ rods fail to grow neurites on the NCAM substrates? The failure of a particular CAM to promote neurite growth could be the result of alternative splicing that generates forms of individual CAMs that differ in function (e.g., Hemperley et al., 1986; Barthels et al., 1987; Santoni et al., 1987; Small et al., 1987; Barton et al., 1988; Doherty and Walsh, 1992). For example, NCAM containing the product of a 30 base pair exon named VASE (Small et al., 1990) cannot stimulate neurite outgrowth (Doherty et al., 1992a-c; Liu et al., 1993). Therefore, P3 rods may not be able to respond to NCAM substrates if they preferentially expressed the VASE containing isoform. In addition, while the knowledgc of the signal-transduction mechanisms regulating neurite growth is poor, stimulation of neurite growth by CAMs is a complex process that may involve activation of conventional second-messenger systems and, perhaps, simultaneous action of other growth regulators (Bixby, 1989; Danilov and Juliano, 1989; Schuch et al., 1989; reviewed in Bixby, 1991; Bixby and Jhabvala, 1992). Signal transduction by CAMs like L1, NCAM, and N-cadherin seems distinct from that involving ECM proteins and integrin receptors (Bixby and Jhabvala, 1992). For example, NCAM and $\mathrm{N}$-cadherin, but not integrins, appear to stimulate neurite growth from PC-12 cells and some neurons through a pertussis toxinsensitive $\mathrm{G}$ protein and activation of $\mathrm{Ca}^{2+}$ channels (Doherty et al., 1991b, 1992c; Saffell et al., 1992). Thus, rods may not respond to a particular substrate due, in part, to intercellular regulation through second messengers.

The failure of $\mathrm{P} 3$ or $\mathrm{P} 10$ rods to respond to $\mathrm{L} 1$ and $\mathrm{N}$-cadherin parallels the distribution of these two CAMs; $\mathrm{L} 1$ immunoreactivity was seen within the plexiform layers, as in other species, and $\mathrm{N}$-cadherin was abundant within both inner and outer plexiform layers, Müller glia, and outer limiting membrane. The localization of $\mathrm{N}$-cadherin in the rat retina using the fusion protein antibody (Doherty et al., 1991a) is similar to the chick (Matsunaga et al., 1988), except that we observed some staining on Müller glial cells. The prevalence of $\mathrm{N}$-cadherin in the outer limiting membrane, a zonula adherens junction rich contact site (Sheffield and Fischman, 1970) between rods and between rods and Müller glial cells, would not be an appropriate site for this molecule to influence rod neurite growth; instead, this localization is more important for keeping the normal histotypic morphology of the photoreceptor cell layer intact, as suggested from previous antibody blocking studies (Matsunaga et al., 1988).

In summary, formation of the complex wiring pattern in the retina involving nonprojection neurons would in the most physiological situation depend on interactions with many different classes of molecules that can effect neurite growth. These molecular factors would include positive regulators of neurite growth such as membrane-bound cell adhesion molecules localized to growth cones and the cellular surfaces that they contact (Dodd and Jessell, 1988; Bixby and Harris, 1991). In addition, these factors must also include inhibitory molecules since, for example, rod photoreceptor cells in culture grew neurites much longer than they normally would within the intact retina. Additionally, RGCs and amacrine cells grew neurites in response to the same CAMs in culture, yet within the intact retina they project processes to different areas which suggests a differential responsiveness to these inhibitory cues. The growth cones of retinal local circuit neurons, like amacrine cells and rods, interact with several cellular substrates including neuroepithelial progenitor cells, Müller glial cells, and the dendrites and axons from other developing neurons. Any combination of these cell surfaces could contain the molecules that regulate the growth of their neurites. In this report, we have made an initial attempt to understand the mechanisms of formation of this complex circuitry in the context of the cell adhesion molecules available to the retinal neurons; we suggest that the selective spatial and temporal developmental regulation of different CAMs is likely to be an important step in the establishment of these circuits.

\section{References}

Baier H, Bonhoffer F (1992) Axon guidance by gradients of a targetderived component. Science 255:472-475.

Barnstable CJ, Dräger UC (1984) Thy-l antigen: a ganglion cell specific marker in rodent retina. Neuroscience 11:847-855.

Barthels D, Santoni MJ, Wille W, Ruppert C, Chaix JC, Hirsch MR, Fontecilla-Camps JC, Goridis C (1987) Isolation and nucleotide sequence of mouse N-CAM cDNA that codes for a $M_{r} 79,000$ polypeptide without a membrane-spanning region. FMBO J 6:907-914.

Barton CH, Dickson JG, Gower HJ, Rowett LH, Pitt W, Elsom VL, Moore SE, Goridis C, Walsh FS (1988) Complete sequence and in vitro expression of a tissue-specific phosphatidylinositol-linked N-CAM isoform from skeletal muscle. Development 104:164-173.

Bartsch U, Kirchhoff F, Schachner M (1989) Immunohistological localization of the adhesion molecules L1, N-CAM, and MAG in the developing and optic nerve of mice. J Comp Neurol 284:451-462. 
Bastiani MJ, Harrelson AL, Snow PM, Goodman CS (1987) Expression of fasciclin I and II glycoproteins on subsets of axon pathways during neuronal development in the grasshopper. Cell 48:745-755.

Bixby JL (1989) Protein kinase $\mathrm{C}$ is involved in laminin stimulation of neurite outgrowth. Neuron 3:287-297.

Bixby JL, Harris WA (1991) Molecular mechanisms of axonal growth and guidance. Annu Rev Cell Biol 7:117-159.

Bixby JL, Jhabvala P (1992) Inhibition of tyrosine phosphorylation potentiates substrate-induced neurite growth. J Neurobiol 23:468480.

Bixby JL, Zhang R (1990) Purified N-cadherin is a potent substrate for the rapid induction of neurite outgrowth. J Cell Biol 110:12531260.

Blaugrund E, Sharma S, Schwartz M (1992) Ll immunoreactivity in the developing fish visual system. Brain Res 574:244-250.

Boycott BB, Dowling JE (1969) Organization of the primate retina: light microscopy. Philos Trans R Soc Lond [Biol] 255:109-184.

Bunt-Milam AH, Sarri JC (1983) Immunocytochemical localization of two retinoid-binding proteins in vertebrate retina. J Cell Biol 97: 703-712.

Bunt-Milam AH, De Leeuw AM, Gaur VP, Sarri JC (1989) Localization of cellular retinoic acid-binding protein in a subpopulation of GABAergic amacrine cells. Invest Ophthalmol Vis Sci [Suppl] 30: 344.

Burns FR, von Kannen S, Guy L, Raper JA, Kamholz J, Chang S (1991) DM-GRASP, a novel immunoglobulin superfamily axonal surface protein that supports neurite extension. Neuron 7:209-220.

Catsicas S, Catsicas M, Clarke PGH (1987) Long-distance intraretinal connections in birds. Nature 326:186-187.

Chuang W, Lagenaur CF (1990) Central nervous system antigen P84 can serve as a substrate for neurite outgrowth. Dev Biol 137:219232.

Chung WW, Lagenaur CF, Yan TM, Lund JS (1991) Developmental expression of neural cell adhesion molecules in the mouse neocortex and olfactory bulb. J Comp Neurol 314:290-305.

Cohen J, Johnson AR (1991) Differential effects of laminin and merosin on neurite outgrowth by developing retinal ganglion cells. J Cell Sci [Suppl] 15:1-7.

Cohen J, Burne JF, McKinlay C, Winter J (1987) The role of laminin and the laminin/fibronectin receptor complex in the outgrowth of retinal ganglion cell axons. Dev Biol 122:407-418.

Connell GJ, Molday RS (1990) Molecular cloning, primary structure, and orientation of the vertebrate photoreceptor cell protein peripherin in the outer segment disk membrane. Biochemistry 29:4691-4698.

Crooks J, Kolb H (1992) Localization of GABA, glycine, glutamate and tyrosine hydroxylase in the human retina. J Comp Neurol 315 : 287-302.

Dacey DM (1988) Dopamine-accumulating retinal neurons revealed by in vitro fluorescence display a unique morphology. Science 233 : $1196-1198$.

Dacey DM (1989) Axon-bearing amacrine cells of the macaque monkey retina. J Comp Neurol 284:275-293.

Daniloff JK, Chuong CM, Levi G, Edleman GM (1986) Differential distribution of cell adhesion molecules during histogenesis of the chick nervous system. J Ncurosci 6:739-758.

Danilov YN, Juliano RL (1989) Phorbal ester modification of integrinmediated cell adhesion: a postreceptor event. J Cell Biol 108:19251933.

De Leeuw AM, Gaur VP, Saari JC, Milam AH (1990) Immunolocalization of cellular retinol-, retinaldehyde-and retinoic acid-binding proteins in the retina during pre- and postnatal development. J Neurocytol 19:253-264.

DeVries SH, Baylor DA (1993) Synaptic circuitry of the retina and olfactory bulb. Cell 72/Neuron 10[Suppl]:139-149.

Dodd J, Jessell TM (1988) Axon guidance and the pattern of neuronal projections in vertebrates. Science 242:692-699.

Doherty P, Walsh FS (1992) Cell adhesion molecules, second messengers and axonal growth. Curr Opin Neurobiol 2:595-601.

Doherty P, Fruns M, Seaton P, Dickson G, Barton CH, Sears, Walsh FS (1990a) A threshold effect of the major isoforms of N-CAM on neurite outgrowth. Nature 343:464-466.

Doherty P, Cohen J, Walsh FS (1990b) Neurite outgrowth in response to transfected N-CAM changes during development and is modulated by polysialic acid. Neuron 5:209-219.

Doherty P, Rowett LH, Moore SE, Mann DA, Walsh FS (1991a) Neurite outgrowth in response to transfected N-CAM and N-cadherin reveals fundamental differences in neuronal responsiveness to CAMs. Neuron 6:247-258

Doherty P, Ashton S, Moore SE, Walsh FS (1991b) Morphoregulatory activities of NCAM and N-cadherin can be accounted for by $\mathrm{G}$ protein-dependent activation of $\mathrm{L}$ - and $\mathrm{N}$-type neuronal $\mathrm{Ca}^{2+}$ channels. Cell 67:21-33.

Doherty P, Moolenaar DE, Ashton SV, Michalides RJ, Walsh FS (1992a) The VASE containing exon downregulates the neurite growth-promoting activity of NCAM 140. Nature 356:791-793.

Doherty P, Rimon G, Mann DA, Walsh FS (1992b) Alternative splicing of the cytoplasmic domain of NCAM alters its ability to act as a substrate for neurite outgrowth. J Neurochem 58:2338-2341.

Doherty P, Skaper SE, Moore SE, Leon A, Walsh FS (1992c) A developmentally regulated switch in neuronal responsiveness to NCAM and N-cadherin in the rat hippocampus. Development 115:885-892.

Drazba J, Lemmon V (1990) The role of cell adhesion Inolecules in neurite outgrowth on Müller cells. Dev Biol 138:82-93.

Durbec P, Gennarini G, Goridis C, Rougon G (1992) A soluble form of the F3 neuronal cell adhesion molecule promotes neurite outgrowth. J Cell Biol 117:877-887.

el-Deeb S, Thompson SC, Covault J (1992) Characterization of a cell surface adhesion molecule expressed by a subset of developing chick neurons. Dev Biol 149:213-227.

Famiglietti EV (1992) Polyaxonal a macrine cells of rabbit retina: PA2, PA3, and PA4 cells. Light and electron microscopic studies with a functional interpretation. J Comp Neurol 316:422-46.

Furley AJ, Morton SB, Manalo D, Karagogeos D, Dodd J, Jessell TM (1990) The axonal glycoprotein TAG-1 is an immunoglobulin superfamily member with neurite outgrowth-promoting activity. Cell 61 : $157-170$.

Gaur VP, De Leeuw AM, Milam AH, Saari JC (1990) Localization of cellular retinoic acid-binding protein to amacrine cells of rat retina. Exp Eye Res 50:505-511.

Giovanni C, Brecha NC (1993) Postnatal development of tyrosine hydrolase immunoreactive amacrine cells in the rabbit retina. I. Morphological characterization. Comp Neurol, in press.

Grunwald GB, Pratt RS, Lilien J (1982) Enzymatic dissection of embryonic cell adhesive mechanisms. III. Immunological identification of a component of the calcium-dependent adhesive system of embryonic chick neural retina cells. J Cell Sci 55:69-83.

Halfter W, Diamantis I, Monard D (1988) Migratory behavior of cells on embryonic retina basal lamina. Dev Biol 130:259-275.

Hatta K, Takeichi M (1986) Expression of N-cadherin adhesion molecules associated with early morphogenetic events in chick development. Nature 320:447-449.

Hatta K, Okada TS, Takeichi M (1985) A monoclonal antibody disrupting calcium-dependent cell-cell adhesion of brain tissues: a possible role of its target antigen in animal pattern formation. Proc Natl Acad Sci USA 82:2789-2793.

Hemperley JJ, Edelman GM, Cunningham BA (1986) cDNA clones of the neural cell adhesion molecule (NCAM) lacking a membranespanning region consistent with evidence for membrane attachment via a phosphatidylinositol intermediate. Proc Natl Acad Sci USA 83: 9822-9826.

Hicks D, Barnstable C (1987) Different rhodopsin monoclonal antibodies reveal different binding patterns on developing and adult rat retina. J Histochem Cytochem 35:1317-1328.

Hinds JW, Hinds PL (1978) Early development of amacrine cells in the mouse retina: an electron microscope, serial section analysis. $J$ Comp Neurol 179:277-300.

Hinds JW, Hinds PL (1979) Differentiation of photoreceptors and horizontal cells in the embryonic mouse retina: an electron microscopic, serial section analysis. J Comp Neurol 187:495-512.

Hoffman S, Friedlander DR, Chuong CM, Grumet M, Edelman GM (1986) Differential contributions of $\mathrm{NgCAM}$ and NCAM to cell adhesion in different neural regions. J Cell Biol 103:145-158.

Kadmon G, Kowitz A, Altevogt P, Schachner M (1990) The neural cell adhesion molecule NCAM enhances L1-dependent cell-cell interactions. J Cell Biol 110:193-208.

Kaneko A (1970) Physiological and morphological identification of horizontal, bipolar and amacrine cells in goldfish retina. J Physiol (Lond) 213:95-105.

Kljavin IJ, Reh TA (1991) Müller cells are a preferred substrate for in vitro neurite extension by rod photoreceptor cells. J Neurosci 11 : 2985-2994.

Kolb H, Nelson R, Mariani A (1981) Amacrine cells, bipolar cells 
and ganglion cells of the cat retina: a Golgi study. Vision Res 21: $1081-1114$.

Krayanek S, Goldberg S (1981) Oriented extracellular channels and axonal guidance in the embryonic chick retina. Dev Biol 84:41-50.

Lagenaur C, Lemmon V (1987) An L1-like molecule, the 8D9 antigen, is a potent substrate for neurite extension. Proc Natl Acad Sci USA $84: 7753-7757$

Lemmon V, McLoon SC (1986) The appearance of an Ll-like molecule in the chick primary visual pathway. J Neurosci 6:2987-2994.

Lemmon V, Farr K, Lagenaur C (1989) L1 mediated axon outgrowth occurs via a homophilic binding mechanism. Neuron 2:1597-1603.

Liu L, Haines S, Shew R, Akeson RA (1993) Axon growth is enhanced by NCAM lacking the VASE exon when expressed in either the growth substrate or growth cone. J Neurosci Res 35:327-345.

Marc RE (1986) Neurochemical stratification in the inner plexiform layer of the vertebrate retina. Vision Res 26:223-238.

Martini R, Schachner M (1988) Immunoelectron microscopic localization of neural cell adhesion molerules ( $\mathrm{L}, 1, \mathrm{~N}-\mathrm{CAM}$, and myelinassociated glycoprotein) in regenerating adult mouse sciatic nerve. J Cell Biol 106:1735-1746.

Matsunaga M, Hatta K, Nagafuchi A, Takeichi M (1988a) Guidance of optic nerve fibers by $\mathrm{N}$-cadherin adhesion molecules. Nature 334: 62-64.

Matsunaga M, Hatta K, Takeichi M (1988b) Role of N-cadherin cell adhesion molecules in the histogenesis of neural retina. Neuron 1:289295.

McLoon SC (1984) Distribution of laminin in the developing visual system of the chick. Soc Neurosci Abstr 10:466.

McLoon S, McI oon LK, Palm SI., Furcht IT (1988) Transient expression of laminin in the optic nerve of the developing rat. J Neurosci 8:1981-1990.

Milam AH, De Lecuw AM, Gaur VP, Saari JC (1990) Immunolocalization of cellular retinoic acid binding protein to Müller cells and/ or a subpopulation of GABA-positive amacrine cells in retinas of different species. J Comp Neurol 296:123-129.

Morest DK (1970) The pattern of neurogenesis in the retina of the rat. J Anat Entwicklungsgesch 131:45-67.

Olney JW (1968) An electron microscopic study of synapse formation, receptor outer segment development, and other aspects of developing mouse retina. Invest Ophthalmol 7:250-268.

Patel NH, Snow PM, Goodman CS (1987) Characterization and cloning of fasciclin III: a glycoprotein expressed on a subset of neurons and axon pathways in Drosophila. Cell 48:975-988.

Payne HR, Burden SM, Lemmon V (1992) Modulation of growth cone morphology by substrate-bound adhesion molecules. 2:65-73.

Perry VH (1981) Evidence for an amacrine cell system in the ganglion cell layer of the cat retina. Neurosci Lett 6:931-944.

Perry VH, Walker M (1980) Morphology of cells in the ganglion cell layer during development of the rat retina. Proc R Soc Lond [Biol] 208:433-445.

Perry VH, Henderson Z, Linden R (1983) Postnatal changes in retinal ganglion cell and optic axon populations in the pigmented rat. J Comp Neurol 219:356-368.

Perry VH, Morris RJ, Raisman G (1984) Is Thy-1 expressed only by ganglion cells and their axons in the retina and optic nerve? J Neurocytol 13:809-824.

Persohn E, Schachner M (1987) Immunoelectron-microscopic localization of the neural cell adhesion molecules $\mathrm{Ll}$ and N-CAM during postnatal development of the mouse cerebellum. J Cell Biol 105:569576

Polyak SL (1941) The retina. Chicago: University of Chicago.

Porter RR (1959) The hydrolysis of rabbit gamma-globulin and antibodies with crystallin papain. Biochem $\mathrm{J}$ 73:119-126.

Ragar GH (1980) Development of the retinotectal projection in the chicken. Adv Anat Embryol Cell Biol 63:63.

Ramon y Cajal S (1973) The vertebrate retina (Rodieck RW, ed; Maguire D, Rodieck RW, trans), pp 781-904. San Francisco: Freeman.

Rathjen FG, Schachner M (1984) Immunocytochemical and biochemical characterization of a new neuronal cell surface component $(\mathrm{Ll}$ antigen) which is involved in cell adhesion. EMBO J 3:1-10.

Rodieck RW (1988) The primate retina. Comp Primate Biol 4:203278
Rutishauser U, Jessell M (1988) Cell adhesion molecules in vertebrate neural development. Physiol Rev 68:819-857.

Rutishauser U, Gall WE, Edelman GM (1978) Adhesion among neural cells of the chick embryo. IV. Role of the cell surface molecule NCAM in the formation of neurite bundles in cultures of spinal ganglia. $J$ Cell Biol 79:382-393.

Rutishauser II, Hoffman S, Fdelman GM (1982) Binding properties of a cell adhesion molecule from neural tissue. Proc Natl Acad Sci USA 79:685-689.

Rutishauser U, Acheson $\Lambda K$, Mann DM, Sunshine J (1988) The ncural cell adhesion molecule (NCAM) as a regulator of cell-cell interactions. Science 240:53-57.

Saffell JL, Walsh FS, Doherty P (1992) Direct activation of second messenger pathways mimics cell adhesion molecule-dependent neurite outgrowth. J Cell Biol 118:663-670.

Santoni MJ, Barthels D, Barbas JA, Hirsch MR, Steinmetz M, Goridis C, Willie W (19870 Analysis of cDNA clones that code for the transmembrane forms of the mouse neural cell adhesion molecule (N-CAM) are generated by alternative splicing. Nucleic Acids Res 15 : $7155-7174$

Sarthy PV, Curtis BM, Cattcrall WA (1983) Retrograde labclling, cnrichment, and characterization on retinal ganglion cells from neonatal rat. J Neurosci 3:2532-2544.

Schuch U, Lohse MJ, Schachner M (1989) Neural cell adhesion molecules influence second messenger systems. Neuron 3:13-20.

SheppardAM,KonopkaM,RobinsonSR,MorganIG,JeffreyPL (1991)Thy-1 antigen is specific to ganglion cells in chicks. Neurosci Lett 123:8790.

Sidman RI (1961) Histogenesis of the mouse retina studied with thymidine- $\mathrm{H}^{3}$. In: The structure of the eye (Smelser GK, ed), pp 487506. New York: Academic.

Sidman RL, Wesscls N (1975) Control of direction of growth during elongation of neurites. Exp Neurol 48:237-251.

Silver J, Rutishauser U (1984) Guidance of optic nerve axons in vivo by a preformed pathway on neuroepithelial endfeet. Dev Biol 106: $485-499$.

Silver J, Sidman RL (1980) A mechanism for the guidance and topographic patterning of retinal ganglion cell axons. J Comp Neurol 189:101-111.

Small SJ, Akeson $\mathbf{R}$ (1990) Fxpression of the unique NCAM VASE exon is independently regulated in distinct tissue during development. J Cell Biol 111:2089-2096.

Small SJ, Shull GE, Santoni MJ, Akcson R (1987) Identification of a cDNA clone that contains the complete coding sequence for a $140-$ kD rat N-CAM polypeptide. J Cell Biol 105:2335-2345.

Snow DM, Letourneau PC (1992) Neurite outgrowth on a step gradient of chondroitin sulfate proteoglycan (CS-PG). Neurobiology 23:322336.

Snow DM, Watanabe M, Letourneau PC, Silver J (1991) A chondroitin sulfate proteoglycan may influence the direction of retinal ganglion cell outgrowth. Development 113:1473-1485.

Stoeckli ET, Kuhn TB, Duc CO, Ruegg MA, Sonderegger P (1991) The axonally secreted protein axonin- 1 is a potent substratum for neuritc growth. J Cell Biol 112:449-455.

Tanaka H, Matsui T, Agata A, Tomura M, Kubota I, McFarland KC, Kohr B, Lee A, Philips HS, Shelton DL (1991) Molecular cloning and expression of a novel adhesion molecule, SC1. Neuron 7:535545.

Thiery J-P, Delouvee A, Grumet M, Edelman GM (1985) Initial appearance and regional distribution of the neuron-glia cell adhesion molecule in the chick embryo. J Cell Biol 100:442-456.

Vaney DI (1984) "Coronate" amacrine cells in the rabbit retina have a "starburst" dendritic morphology. Proc R Soc Lond [Biol] 220:501508.

Vaney DI, Peichl L, Boycotı BB (1988) Neurofibrillar long range amacrine cells in mammalian retinae. Proc R Soc Lond [Biol] 235:203219.

Werblin FS, Dowling JE (1969) Organization of the retina of the mudpuppy Necturus maculosus. II. Intracellular recording. J Neurophysiol 32:339-355. 